HOSPITAL DE REABILITAÇÃO DE ANOMALIAS CRANIOFACIAIS UNIVERSIDADE DE SÃO PAULO

\title{
“ANÁLISE DO PERFIL MOLE FACIAL FRENTE AO AVANÇO CIRÚRGICO DE MAXILA EM PACIENTES COM FISSURAS
} LABIOPALATINAS"

GUSTAVO LARA ACHÔA

Dissertação apresentada ao Hospital de Reabilitação de Anomalias Craniofaciais da Universidade de São Paulo para obtenção do título de MESTRE em Ciências da Reabilitação.

Área de concentração: Fissuras Orofaciais e Anomalias Relacionadas 
HOSPITAL DE REABILITAÇÃO DE ANOMALIAS CRANIOFACIAIS UNIVERSIDADE DE SÃO PAULO

\section{“ANÁLISE DO PERFIL MOLE FACIAL FRENTE AO AVANÇO CIRÚRGICO DE MAXILA EM PACIENTES COM FISSURAS} LABIOPALATINAS"

GUSTAVO LARA ACHÔA ORIENTADORA: PROFA. DRA. TERUMI OKADA OZAWA

Dissertação apresentada ao Hospital de Reabilitação de Anomalias Craniofaciais da Universidade de São Paulo para obtenção do título de MESTRE em Ciências da Reabilitação.

Área de concentração: Fissuras Orofaciais e Anomalias Relacionadas 


\section{UNIVERSIDADE DE SÃO PAULO \\ HOSPITAL DE REABILITAÇÃO DE ANOMALIAS CRANIOFACIAIS}

Rua Silvio Marchione, 3-20

Caixa Postal: 1501

17043-900 Bauru/SP - Brasil

Telefone: (14)3235-8000

Profa. Dra. Suely Vilela - Reitora da USP

Prof. Dr. José Alberto de Souza Freitas - Superintendente HRAC - USP

Autorizo, exclusivamente, para fins acadêmicos e científicos, a reprodução total ou parcial deste trabalho.

Gustavo Lara Achôa

Bauru, 30 de Janeiro de 2008.

A47a Achôa, Gustavo Lara

Análise do perfil mole facial frente ao avanço cirúrgico de maxila em pacientes com fissuras labiopalatinas/ Gustavo Lara Achôa. Bauru, 2008. 70fls.: il.; $30 \mathrm{~cm}$

Dissertação (Mestrado - Fissuras Orofaciais e anomalias Relacionadas) - HRAC/USP.

Orientadora: Profa ${ }^{a}$. Dra ${ }^{\mathrm{a}}$. Terumi Okada Ozawa

Descritores: 1.Osteotomia Le Fort I. 2.Fissura Labial. 3.Fissura Palatina. 4.Cefalometria. 


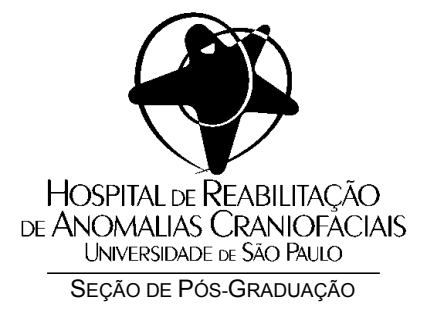

FOLHA DE APROVAÇÃO

Dissertação apresentada e defendida por

GUSTAVO LARA ACHÔA

e aprovada pela Comissão Julgadora em

1

Prof.(a) Dr.(a):

Instituição:

Prof.(a) Dr.(a):

Instituição:

Prof.(a) Dr.(a):

Instituição:

Profa. Dra. Inge Elly Kiemle Trindade

Presidente da Comissão de Pós-Graduação do HRAC-USP

Data de depósito da dissertação junto à CPG: 30/01/2008 


\section{GUSTAVO LARA ACHÔA}

$10 / 03 / 1978$

$1997-2000$

2001-2003

2003-2005

2005-2008

2006 - atual
Nascimento Bauru - SP

Graduação em Odontologia pela Universidade do Sagrado Coração / Bauru - SP

Especialização em Cirurgia e Traumatologia Buco-MaxiloFacial pela APCD / Bauru - SP

Professor de Cirurgia Oral na Faculdade de Odontologia do Instituto Tocantinense Presidente Antônio Carlos e Cirurgião Buco-Maxilo-Facial do Hospital Regional de Araguaína / Araguaína-TO

Curso de Pós-Graduação em Ciências da Reabilitação, subárea em Fissuras Orofaciais e Anomalias Relacionadas, nível Mestrado, no Hospital de Reabilitação de Anomalias Craniofaciais/USP / Bauru - SP

Cirurgião Buco-Maxilo-Facial do Centrinho Prefeito Luiz Gomes da Prefeitura Municipal de Joinville-SC.

Cirurgião Buco-Maxilo-Facial do Hospital Regional Hans Dieter Schmidt / Joinville-SC 


\section{DEDICATÓRIA}


Dedico este trabalho à Juliana, minha amada e tão querida companheira. Do momento em que nos conhecemos até sempre, com a mesma força, carinho, dedicação e amor por nós mesmos e por estes que precisam tanto de nós. Aos meus irmãos Landios, exemplo de pai e homem, e Ana pelo exemplo profissional e otimismo. A minha mãe Regina e meu avô Theódulo, pessoas que sempre me educaram enquanto crescia e ainda educam. A todos os meus professores que me ensinaram algo em minha vida. Tenho certeza que este trabalho é a recompensa. Aos pacientes. Este trabalho tem um maior objetivo, vocês! 
AGRADECIMENTOS 
A Deus,

A minha família,

E a Jú, por estarem sempre ao meu lado.

Agradeço também:

Ao Dr. Roberto Macoto Suguimoto, por sua inteligência e destreza na execução de tão delicado e valoroso trabalho, meio para este estudo;

A Dra. Roberta Martinelli e ao Dr. Renato Facco, pela possibilidade de observar e

aprender;

Ao Prof. Dr. José Alberto de Souza Freitas - Tio Gastão, superintendente do HRACUSP, por ter seguido seu sonho e nele encontrado a dedicação amorosa de tantos;

A Profa. Dra. Inge Elly Kiemle Trindade, coordenadora do Programa de PósGraduação HRAC-USP, pela dedicação especial à formação de seus alunos; A Profa. Dra. Terumi Okada Ozawa, minha orientadora que, sempre muito ligeira, ensinou como eu devo ser autêntico e fazer meu trabalho com mais e mais paixão. Obrigado pelo estímulo!

Ao estatístico, Marcel Taga, pela grande ajuda e muita paciência; Ao pessoal da Secretaria de PG, Andréia, Rogério, Saulo e Zezé, pelo apoio e competência;

Aos demais funcionários do HRAC pelo empenho e pela simpatia; A Sra. Ligia Nunes, coordenadora do Centrinho de Joinville-SC, pela paciência e ajuda nos momentos de ausência para concluir este trabalho. E, em especial, aos pacientes, que me ajudaram a crescer profissionalmente e pessoalmente. 


\section{SUMÁRIO}

1. INTRODUÇÃO

2. REVISÃO DE LITERATURA

3. PROPOSIÇÃO

4. MATERIAL E MÉTODO

4.1 Pacientes

4.2 Análise Cefalométrica

5. RESULTADOS

6. DISCUSSÃO 56

7. CONCLUSÃO 63

8. REFERÊNCIAS BIBLIOGRÁFICAS 65

ANEXOS 


\section{RESUMO}

Achôa GL. Análise do perfil mole facial frente ao avanço cirúrgico de maxila em pacientes com fissuras labiopalatinas. [Dissertação]. Bauru: Hospital de Reabilitação de Anomalias Craniofaciais, Universidade de São Paulo; 2007.

Objetivo: Avaliar as alterações cefalométricas induzidas em tecidos duros e moles em pacientes com fissuras transforame incisivo bilaterais (FTIB) submetidos ao avanço cirúrgico da maxila e o efeito de tal procedimento sobre o perfil mole.

Modelo: Estudo retrospectivo que comparou um tempo pré-operatório imediato a outro pós-operatório mínimo de seis meses, por meio de telerradiografias cefalométricas em norma lateral e cefalometria computadorizada, de indivíduos com fissuras labiopalatinas.

Local: Clínica de Odontologia, HRAC/USP.

Participantes: 8 pacientes do sexo feminino e 17 do sexo masculino, entre 15 e 35 anos, com média de 20,56 anos de idade, que foram submetidos ao tratamento de reabilitação com cirurgia ortognática envolvendo avanço de maxila.

Variáveis: Diferenças entre os períodos pré e pós-operatório de pontos cefalométricos definidos em maxila e perfil mole, Ângulo Naso-Labial (ANL) e distâncias representativas do comprimento (Sn-Sts) e espessura (Ls-Sts) labial superior, além das proporções da movimentação do tecido mole em relação à movimentação do tecido duro de suporte.

Resultados e Conclusão: As alterações cefalométricas no sentido horizontal ocorreram em todos os pontos estudados, em tecido duro e mole; no sentido vertical, apenas os pontos Pró-nasal (Prn), Subnasal (Sn) e A' tiveram alterações significantes; o aumento significante do ANL e Sn-Sts também foi observado. As proporções entre a movimentação óssea e a acomodação do tecido mole do perfil facial são menores que as proporções obtidas nos estudos similares em pacientes com outros tipos de fissura e pacientes sem fissuras, porém no mesmo sentido e direção.

DESCRITORES: Osteotomia Le Fort I, Fissura Labial, Fissura Palatina, Cefalometria. 


\section{SUMMARY}

Achôa GL. Analysis of the facial soft tissues following surgical maxillary advancement in cleft lip and palate patients. [Dissertation]. Bauru: Hospital for Rehabilitation of Craniofacial Anomalies, University of São Paulo; 2007.

Objective: To assess cephalometric changes in hard and soft tissues of bilateral cleft lip and palate (BCLP) patients following surgical maxillary advancement and its effect over the soft tissue profile.

Design: Retrospective study which compares an immediately pre surgical to a post surgical moment, at least six months later, through cephalometric lateral radiographs and a cephalometry computer program, of individuals with cleft lip and palate.

Setting: Clinic of Dentistry, HRCA/USP.

Subjects: 8 women and 17 men, from 15 to 35 years old and mean age of 20.56, underwent orthognathic surgery with maxillary advancement during the rehabilitation treatment.

Variables: Changes between different cephalometric landmarks from pre surgical to post surgical periods in hard and soft tissue of maxilla, Nasolabial angle (NLA) and distances representing the length (Sn-Sts) and thickness (StsLs) of the upper lip, besides the ratios of soft tissue changes relative to hard tissue movements.

Results and Conclusion: Horizontal cephalometric changes happened to all of the studied landmarks in both maxilla and soft tissue profile; vertically, only Pronasale (Prn), Subnasale (Sn) and A' showed significant changes; the significant increasing of NLA and Sn-Sts also was observed. The ratios of facial profile soft tissue changes relative to bone movement were smaller than ratios observed in patients with other cleft types and patients with no clefts, however, this changes remain in the same directions.

DESCRIPTORS: Le Fort I Osteotomy, Cleft Lip, Cleft Palate, Cephalometry. 
INTRODUĢÃO 


\section{INTRODUÇÃO}

Ao início do tratamento das fissuras labiopalatinas as cirurgias plásticas de fechamento, classificadas como cirurgias primárias, são realizadas no intuito de corrigir estética e funcionalmente a alteração, mas, também, de aliviar o anseio por parte dos pais do paciente (Trindade e Silva Filho 2007).

Embora as queiloplastias e palatoplastias primárias precoces sejam sempre desejáveis em primeira instância, o crescimento maxilar pode ser negativamente influenciado pela intervenção cirúrgica, interrupção da vascularização ou formação de cicatrizes locais. Além de um encurtamento e/ou assimetria labial resultante das cirurgias primárias executadas na infância (Braun e Soltereanos 1980), o lábio superior de indivíduos com fissuras, primariamente reparadas, é menos espesso e flexível. Isto influencia na conformação do lábio inferior que se torna evertido, com aparência hipertrofiada, devido à distância intercomissural diminuída pela cirurgia do lábio superior, e uma hipertrofia crônica da musculatura do mento em razão da compensação do lábio inferior na oclusão deficiente do lábio superior (Ewing e Ross 1993).

Segundo Tindlund e Rygh (1993), o tratamento ortopédico com tração reversa da maxila de crianças com fissuras labiopalatinas, em crescimento e desenvolvimento, comparado com o mesmo tratamento de crianças sem fissuras da mesma idade, de forma geral, resulta em um movimento anterior significativo do ápice nasal e lábio superior, tanto para fissuras unilaterais quanto bilaterais. Isto traz uma harmonia do perfil facial 
mais satisfatória, com base no reposicionamento anterior precoce da base óssea maxilar.

Mesmo com estas compensações precoces induzidas na maxila, em muitos casos, a terapia ortodôntica corretiva subseqüente torna-se um desafio, uma vez que a possibilidade de grandes movimentações é limitada pela ausência de crescimento, menor metabolismo e deficiências periodontais associadas.

Por tal demanda, a reconstrução do terço médio da face vem se tornando, progressivamente, um procedimento rotineiro praticado em hospitais especializados na reabilitação de pacientes com fissuras orofaciais, de forma multidisciplinar, incluindo os tratamentos cirúrgico, ortodôntico e protético (Braun e Soltereanos 1980).

Os pacientes acometidos pelas fissuras labiopalatinas freqüentemente requerem, como tratamento corretivo, o avanço cirúrgico maxilar, combinado ou não às intervenções mandibulares (Baumann e Sinko 2003), ao final de seu crescimento facial. Tal procedimento é clinicamente importante no aspecto estético, funcional e psicossocial do indivíduo (AlWaheidi e Harradine 1998 e Silva Filho et al 2000) e sua predictibilidade de extrema necessidade. Dentro desta necessidade e da alteração na conformação labial provocada pela fissura em si e as cirurgias primárias, a previsão de movimentação dos tecidos moles da face torna-se um fator essencial.

Em pesquisas subjetivas realizadas no Hospital de Reabilitação de Anomalias Craniofaciais - USP observou-se que: tanto nos pacientes com fissuras transforame incisivo bilaterais (FTIB) ainda em crescimento, que 
receberam as cirurgias primárias, quanto nos pacientes com FTIB que receberam o protocolo de reabilitação completo, o nariz, o terço médio da face e o lábio superior ainda são as estruturas destacadas como responsáveis pela má estética facial (Ferrari Júnior 2005 e Lauris 2005). Nos pacientes com fissuras transforame incisivo unilaterais (FTIU), o nariz, o terço médio e o mento mostram maior influência na deficiência estética da face (Almeida 2005).

Cefalometricamente, o perfil mole facial pode ser proporcional ao tecido ósseo subjacente, no sentido de facilitar a previsão e aumentar as chances de sucesso estético do tratamento ortodôntico-cirúrgico.

Tal proporção pode apresentar resultados duvidosos quando a base de avaliação for um período pós-operatório muito curto (menor que 6 meses). A causa da recidiva do avanço cirúrgico de maxila utilizando a osteotomia tipo LeFort I é considerada multifatorial. Condições como a mobilização tecidual, aproximação das paredes ósseas, qualidade óssea, enxertos interposicionais, presença de fissuras, cirurgias prévias e tipo de fixação são consideradas muito importantes (Mehra et al 2001). No controle pós-operatório deste procedimento, o maior tempo está diretamente relacionado com medidas maiores de recidiva (Heliövaara et al 2002 e Suguimoto 2002), portanto, os valores são mais precisos em longo prazo (Ewing e Ross 1993). Ainda assim, deve-se considerar um tempo padrão de análise pós-cirúrgica como base para comparação aos períodos posteriores, tendo em vista o objetivo a ser alcançado.

A análise do perfil facial de pacientes sem fissuras em resposta à movimentação óssea maxilar ou mandibular tem sido bem quantificada na literatura. A estética final obtida pela cirurgia ortognática sempre foi um ponto 
relevante no julgamento do sucesso do tratamento, se não pelo cirurgião, certamente pelo paciente (Sarver e Johnston 1993). 
REVISÃO DE LITERATURA 


\section{REVISÃO DE LITERATURA}

\section{- Considerações gerais}

Incompetências de tecidos moles faciais, tais como fístulas oronasais, deformidades do lábio superior, ápice nasal, bases alares e contração cicatricial labial, são resultados de intervenções cirúrgicas prévias e ausência de suporte ósseo em pacientes com fissuras labiopalatinas (Braun e Soltereanos 1980). Por meio de uma revisão da literatura, os mesmos autores citam as causas e os tratamentos do pseudoprognatismo, deficiência maxilar unilateral e bilateral, insuficiência alveolar e fístula oronasal em pacientes com fissuras, dando ênfase à cirurgia ortognática, reconstrução alveolar e cirurgias plásticas. Ao compararem os dados encontrados na literatura, os autores concluíram que a atuação multidisciplinar é indispensável neste tipo de tratamento.

Enfaticamente, Tindlund e Rygh (1993) afirmam a necessidade da ortopedia precoce no tratamento da deficiência maxilar em crianças com fissuras labiopalatinas. Estes autores descreveram as mudanças no perfil mole de face destes pacientes, obtidas pela expansão ou tração maxilar, tanto com fissuras unilaterais quanto bilaterais, com idade entre 6 anos e 5 meses e 7 anos e 3 meses, em comparação ao crescimento e desenvolvimento de pacientes sem fissuras. Neste estudo, modificações benéficas foram alcançadas pelos indivíduos submetidos à tração maxilar, tanto no posicionamento labial quanto nasal. 
Aiello (2005), avaliando 30 pacientes com FTIU submetidos ao protocolo de expansão e tração reversa de maxila (TRM), demonstrou que os efeitos ortopédicos do avanço anterior da maxila somados aos efeitos dentários, promovem a melhora do perfil esquelético e tegumentar do ponto de vista cefalométrico, porém de magnitude insatisfatória em relação à melhora da estética facial.

lannetti et al (2004) ressaltam que o acompanhamento ortodôntico é preciso para averiguar se o crescimento da maxila está sendo afetado pela cicatriz labial e como assegurá-lo, além de avaliar o momento adequado de realização da cirurgia ortognática, quando necessária. A osteotomia LeFort I seria o tratamento mais indicado para os pacientes que terminaram seus crescimentos e sofrem os efeitos das cicatrizes labiais. Variações de técnica, fixação rígida, e manutenção da vascularização são necessárias para evitar complicações e recidivas pós-operatórias.

Silva Filho et al (2000), analisando as condutas terapêuticas adotadas no Hospital de Reabilitação de Anomalias Craniofaciais da Universidade de São Paulo para o tratamento de pacientes com fissuras transforame, citam a importância da cirurgia ortognática na correção da hipoplasia maxilar (deficiência de maxila) quando as correções ortopédica e ortodôntica chegam aos seus limites.

O processo de planejamento ortodôntico-cirúrgico requer uma síntese entre o julgamento clínico, a observação das relações funcionais entre tecidos moles e o tecido ósseo subjacente, conhecimento da resposta dos tecidos moles à movimentação óssea e a experiência dos clínicos envolvidos (Sarver e Johnston 1993). 


\section{- Estudos Clínicos}

Sarver e Johnston (1993) descreveram dois casos clínicos para ilustrar o plano de tratamento da cirurgia ortognática com objetivos funcionais e estéticos. Neste trabalho os autores fazem uso de programa de imagem computadorizado na previsão estética a fim de estabelecer uma comunicação com os pacientes e fazê-los participar diretamente dos objetivos da cirurgia ortognática, oferecendo, ainda, a possibilidade de procedimentos em tecidos moles, como rinoplastia, otoplastia e outros.

Ewing e Ross (1993) afirmaram que a resposta dos tecidos moles referentes à maxila não é influenciada pela cirurgia mandibular conjunta; que a resposta dos tecidos moles é mais correlacionada aos movimentos horizontais da maxila; e, ainda, que os movimentos maiores que $4 \mathrm{~mm}$ provocam perda em espessura do lábio superior. Este estudo obteve as proporções nas mudanças de tecidos duros e moles em 30 pacientes com FTIU submetidos ao avanço maxilar, utilizando a osteotomia LeFort I, combinado ou não às intervenções mandibulares.

McCance et al (1997a) utilizaram a análise tridimensional dos tecidos moles da face, por scanner a laser, para comparar pacientes com fissuras labiopalatinas a pacientes sem fissuras durante as fases pré e póscirúrgica do avanço da maxila. Tal estudo preliminar avaliou a possibilidade da aplicação desta técnica e estabeleceu os parâmetros de desvio padrão para os lados direito e esquerdo e linha média da face operada, relacionando o padrão pré-operatório e o resultado cirúrgico obtido nos pacientes acometidos por fissuras ao padrão e resultado obtido de pacientes sem fissuras. 
McCance et al (1997b), ao avaliarem 24 pacientes com fissuras labiopalatinas quanto à proporção de movimentação de tecido mole em relação aos tecidos duros após osteotomias LeFort I, utilizando Tomografias Computadorizadas e um sistema de codificação colorida para a análise, obtiveram como resultados uma movimentação de 1:1 na região maxilar, de forma geral, em pacientes com FTIB e, segundo os autores, comprovaram a eficácia do método.

Al-Waheidi e Harradine (1998) estudaram a proporção das mudanças de tecidos duros e moles em 28 pacientes com fissuras labiopalatinas, independentemente do tipo de fissura, submetidos à osteotomia LeFort I para avanço de maxila. Tal estudo demonstrou que o movimento do incisivo superior foi o mais significante na condição pós-operatória do lábio superior, além de não demonstrar diferença na modificação da espessura e do comprimento labiais provocados pelo avanço da maxila, quando comparamos pacientes com fissuras aos sem fissuras.

Heliövaara et al (2000) estabeleceram as proporções (em porcentagem) dos tecidos moles da face de pacientes com FTIU em relação ao avanço cirúrgico da maxila. Por meio de um estudo que avaliou a posição e a estabilidade pré e pós-operatória, com e sem suturas do tipo $\mathrm{V}-\mathrm{Y}$, os autores obtiveram valores de relação horizontal, ou seja, representantes da espessura do lábio superior, em torno de $80 \%$ e, valores de relação vertical de $40 \%$ em um período de seis meses com estabilidade de um ano.

Heliövaara et al (2001) compararam as proporções entre tecidos duros e moles do perfil facial de pacientes com fissuras palatinas, pacientes com FTIU e pacientes com FTIB submetidos à osteotomia LeFort I, excluindo 
as variáveis: cirurgias bimaxilares, rinoplastia simultânea e sutura do tipo V-Y. Os autores obtiveram resultados significativos que demonstravam as diferenças entre os resultados dos diferentes tipos de fissuras frente ao procedimento cirúrgico e, concluíram que, para os pacientes com FTIB, a cirurgia ortognática permite um melhor suporte esquelético para a sustentação dos tecidos moles e melhora nos resultados da plástica labial secundária.

\section{- Metodologia}

Radney e Jacobs (1981) avaliaram a resposta do perfil de tecido mole à intrusão maxilar cirúrgica total realizada para reduzir o excesso maxilar vertical. Radiografias laterais da cabeça de 10 adultos realizadas no préoperatório e, no mínimo, seis meses de pós-operatório, foram comparadas no intuito de avaliar a mudança de tecido duro e mole, usando uma técnica linear de mensuração com base em linha horizontal e vertical de referências criadas a $12^{\circ}$ a partir da base anterior do crânio (Linha Sela - Násio). Os resultados do estudo indicaram que as mudanças de perfil do tecido mole, associadas à intrusão maxilar de cirurgia total, são previsíveis.

Ayoub (1991) realizou um trabalho com o objetivo de estimar a magnitude e duração das mudanças em tecidos moles da face após uma osteotomia maxilar anterior, assim como avaliar os méritos desta técnica cirúrgica no tratamento do excesso maxilar anterior. Neste estudo, foram avaliados 10 adultos dos quais foram feitos cefalogramas pré e pós-operatórios (6 meses) digitalizados, utilizando a análise cefalométrica usada por Radney e Jacobs (1981). O autor concluiu que a recidiva é limitada e as mudanças dos 
tecidos moles em resposta à osteotomia maxilar anterior são mais previsíveis do que em técnicas cirúrgicas mais extensas.

A proposta do estudo realizado por Jensen et al (1992) foi de avaliar a quantidade, direção e predictibilidade das mudanças de tecidos moles associadas com cirurgias de impacção maxilar simultânea à cirurgia de avanço mandibular. A amostra foi constituída de 17 pacientes com boa oclusão, submetidos à osteotomia LeFort I com impacção maxilar vertical e osteotomia sagital de ramo para avanço mandibular, além da sutura de bases alares e a sutura V-Y. A análise cefalométrica foi utilizada com base em Radney e Jacobs (1981). Segundo os autores, os tecidos moles maxilares moveram-se $90 \%$ com relação à movimentação total de impacção dos tecidos duros e mostraram $20 \%$ de encurtamento no lábio superior, além de mudanças do ângulo naso-labial decorrente ao grau de rotação maxilar.

Nary Filho et al (2002) estudaram os efeitos dos procedimentos de expansão maxilar com sutura V-Y sobre o perfil mole da face, utilizando um método linear de análise cefalométrica, com base no trabalho de Radney e Jacobs (1981).

Suguimoto (2002) avaliou a estabilidade da maxila e mandíbula em indivíduos submetidos à cirurgia ortognática de avanço maxilar em pacientes com FTIU, por meio do programa computadorizado Cef-X. Neste estudo, o autor fez uso da análise cefalométrica utilizada por Radney e Jacobs (1981) em um período pós-operatório de 6 meses, 1, 2 e 3 anos, para a comparação com o período pré-operatório imediato, obtendo resultados que demonstraram a recidiva significativa dos pontos cefalométricos $A, B$ e lis no sentido horizontal e, nenhum valor significativo de recidiva no sentido vertical. 
PROPOSIÇÃO 


\section{PROPOSIÇÃO}

Têm-se como objetivos gerais do projeto:

- avaliar as alterações cefalométricas induzidas em tecidos duros e moles em pacientes com fissuras transforame incisivo bilaterais (FTIB) submetidos ao avanço cirúrgico da maxila, mensurando os resultados pré e pós-operatório;

- avaliar o efeito de tal procedimento sobre o perfil mole facial de indivíduos com fissura em relação à quantidade de movimentação.

A presente investigação justifica-se pela ausência de informações a respeito dos efeitos do tratamento das deformidades maxilares através de procedimentos ortodôntico-cirúrgicos sobre os tecidos moles da face em pacientes com fissuras, especificamente em pacientes com FTIB. Trata-se de um tema atual na avaliação de pacientes sem fissuras em relação a um procedimento que se torna cada dia mais rotineiro nos hospitais de reabilitação de anomalias faciais, que carece de informações específicas sobre a alteração do perfil facial em pacientes acometidos por fissuras orofaciais. A avaliação dos tecidos moles e sua proporção em relação à movimentação óssea poderão ser tomadas como base para futuros estudos sobre a influência dos procedimentos executados nas cirurgias ortognáticas em pacientes com fissuras labiopalatinas. 
MATERIAL E MÉTODO 


\section{MATERIAL E MÉTODO}

\subsection{Pacientes}

Para este estudo, autorizado pelo Comitê de Ética em Pesquisa da Unidade de Ensino e Pesquisa segundo o Anexo 1, foram selecionados 25 pacientes junto ao Centro Odontológico do Hospital de Reabilitação de Anomalias Craniofaciais / Universidade de São Paulo - Bauru, submetidos ao tratamento ortodôntico-cirúrgico.

Caracterizaram critérios de inclusão na amostra:

- pacientes leucodermas adultos, acometidos por fissuras transforame incisivo bilaterais (FTIB), com diversos tipos de má oclusão, porém com diagnóstico comum de hipoplasia sagital maxilar. Puderam ser incluídos pacientes com outras discrepâncias de arcos associadas;

- pacientes dentados, tratados ortodôntico-cirurgicamente, submetidos à cirurgia ortognática de avanço maxilar e enxerto ósseo alveolar concomitante;

- operados pelo mesmo cirurgião, empregando a mesma técnica cirúrgica;

- não terem sido submetidos às suturas definidas para o aumento volumétrico do lábio superior;

- não terem sido submetidos à queiloplastia secundária durante o período estudado;

- não terem sido submetidos à rinoplastia e/ou septoplastia no período estudado; 
- ausência de outras deformidades craniofaciais ou síndromes, que acarretem alterações pronunciadas dos tecidos moles;

- não terem sofrido trauma facial com fratura prévia;

- bom estado geral de saúde;

- pacientes que aceitaram a inclusão no estudo através de termo de consentimento livre esclarecido (Anexo 2).

Foram selecionados somente pacientes que tiveram todas as suas documentações radiográficas realizadas em um mesmo tipo de aparelho de raios $\mathrm{X}$, em um mesmo cefalostato, para posicionamento adequado, evitando qualquer diferença entre radiografias.

Radiografias cefalométricas foram obtidas do período préoperatório imediato e pós-operatório mínimo de 6 meses.

Todas as radiografias foram digitalizadas através do "scanner", com adaptadores de transparência e copiadas para o programa computadorizado de cefalometria e análise facial Cef-X (CDT Informática Ltda - Cuiabá, MT).

As medidas pré-operatórias serviram como controle na comparação dos resultados das medidas pós-operatórias.

Os pacientes submetidos ao enxerto alveolar na área da fissura, concomitantemente ao avanço cirúrgico da maxila, foram agrupados para averiguação da influência de tal procedimento no resultado pós-operatório do perfil mole facial.

Desta forma, buscou-se avaliar a proporção entre a movimentação óssea e a posição final do tecido mole do terço médio da face em pacientes com FTIB. 


\subsection{Análise Cefalométrica}

Para este estudo foi utilizada uma análise computadorizada específica para se obter máxima fidelidade dos movimentos maxilares e de tecidos moles.

Os pontos cefalométricos utilizados (Figura 1) são descritos a seguir:

- Pró-nasal (Prn) - ponto mais proeminente do ápice do nariz;

- Pró-nasal médio (Prm) - ponto médio da curvatura da borda inferior do nariz, entre Prn e Sn;

- Espinha nasal anterior (ENA) - ponto mais anterior da espinha nasal anterior;

- Subnasal (Sn) - ponto entre a columela nasal e o filtro do lábio superior;

- Ponto mais posterior da curva do sulco maxilar (A);

- Ponto A do tecido mole $\left(A^{\prime}\right)$ - ponto tegumentar mais posterior da curvatura do sulco maxilar;

- "Labrale superius" ou lábio superior (Ls) - ponto mais proeminente do lábio superior;

- Estômio do lábio superior (Sts) - ponto mais inferior do lábio superior;

- Incisal do incisivo superior (lis) - ponto incisal dos incisivos centrais superiores;

- Ponto Sela (S) - centro geométrico da sela túrsica; 
- Ponto Násio (N) - ponto de encontro entre a sutura do osso frontal com os ossos próprios do nariz;

- Ponto mais posterior do contorno do palato ósseo (ENS);

- Ápice da cúspide distal do segundo molar superior (7).

Foi utilizado um traçado cefalométrico de acordo com os trabalhos de Radney e Jacobs (1981), Ayoub (1991), Jensen et al (1992), Nary Filho et al (2002) e Sugimoto (2002), padronizando-se duas linhas de referência, uma horizontal e outra vertical (Figura 1), descritas a seguir:

a) linha horizontal de referência (LHR): tomada a 12 graus abaixo da linha S-N passando por S (Sela);

b) linha vertical de referência (LVR): traçando uma perpendicular à linha horizontal de referência, partindo de S (Sela).

Antes da digitalização das radiografias, os traçados cefalométricos foram construídos por uma técnica de transferências de estruturas, de forma a minimizar erros na reprodução das estruturas cefalométricas, projetando na radiografia pós-operatória o traçado pré-cirúrgico realizado em papel de acetato 0,07 polegadas de espessura e com lapiseira de grafite 2B de 0,5mm. Foram desenhados: a base do crânio, o osso frontal, os ossos próprios do nariz, a fissura pterigomaxilar e a órbita. Os desenhos foram sobrepostos na telerradiografia pós-operatória do mesmo paciente, para a marcação de dois pontos cefalométricos com alfinete, o ponto $S$ (sela) e o $\mathrm{N}$ (Násio), para obtenção na linha S-N e, a partir desta, a linha horizontal de referência (LHR) e a linha vertical de referência (LVR) (Suguimoto 2002). 
Determinados os pontos cefalométricos e as linhas de referência, foram realizadas as mensurações cefalométricas horizontais e verticais, partindo-se do ponto cefalométrico em questão até alcançar perpendicularmente a linha de referência, obtendo-se o resultado destas mensurações em milímetros. Quanto às medidas cefalométricas, mensurou-se também a distância milimétrica entre os referidos pontos Sn-Sts e Ls-Sts. Foi obtido, além dessas anteriores, uma única medida angular, o ângulo Nasolabial, tomada em graus.

Essas medidas cefalométricas (Figura 2) estão descritas a seguir: Medidas horizontais - distâncias entre os pontos ENA, ENS, 7, A, lis, Prn, Sn, A', Ls, Sts até a linha vertical de referência (LVR). Cada distância caracterizando uma medida horizontal, separadamente.

Medidas verticais - distâncias entre os pontos ENA, ENS, 7, A, lis, Prn, Sn, A', Ls, Sts até a linha horizontal de referência (LHR).

Medidas adicionais - distâncias milimétricas de Sn-Sts e Ls-Sts Medida angular - observação do ANL - Ângulo Naso-labial A utilização das radiografias cefalométricas no programa Cef- $X$ (CDT Informática Ltda - Cuiabá, MT) pode ser observada nas figuras 3 e 4. 


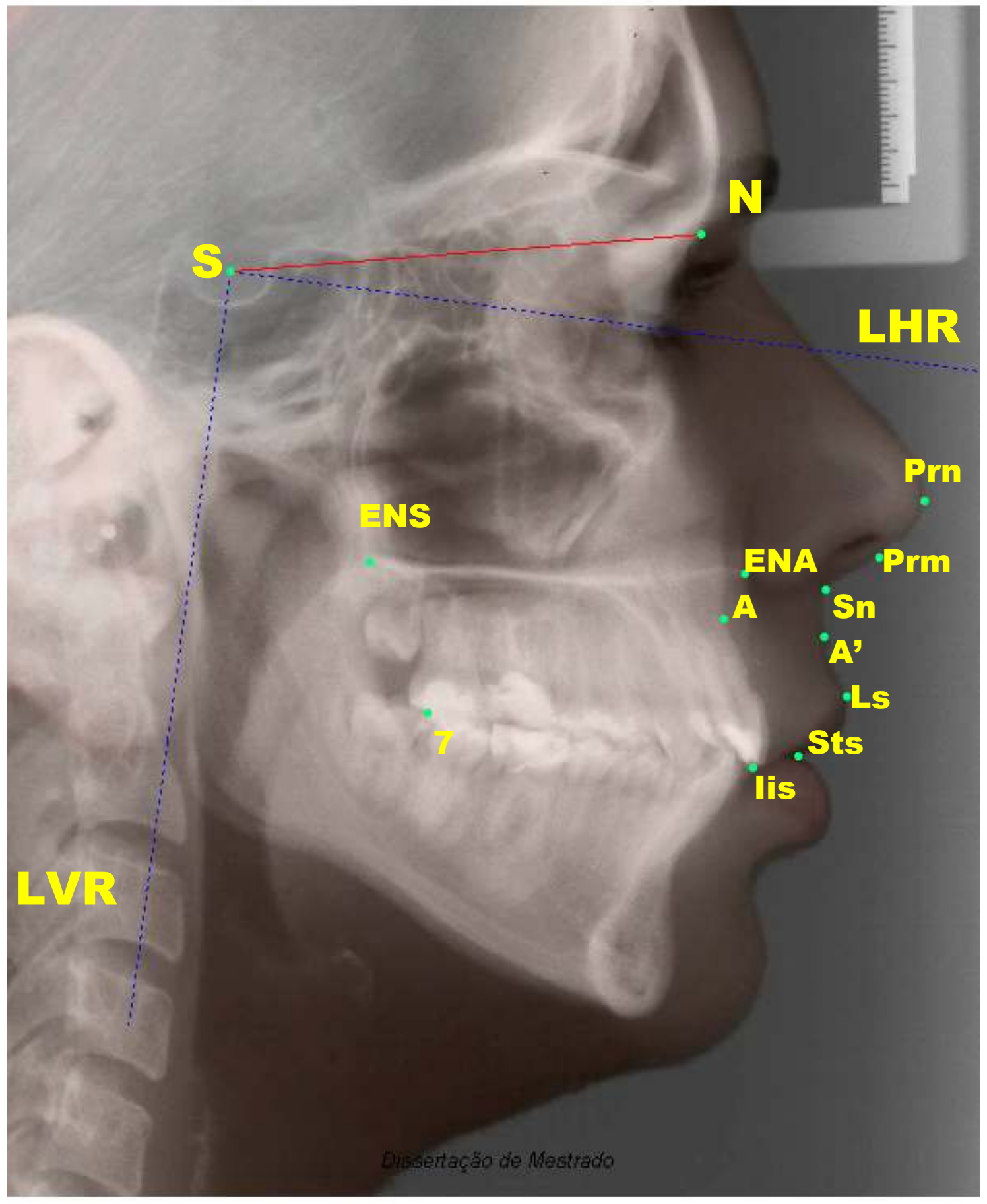

Figura 1 - Pontos cefalométricos e linhas de referência 


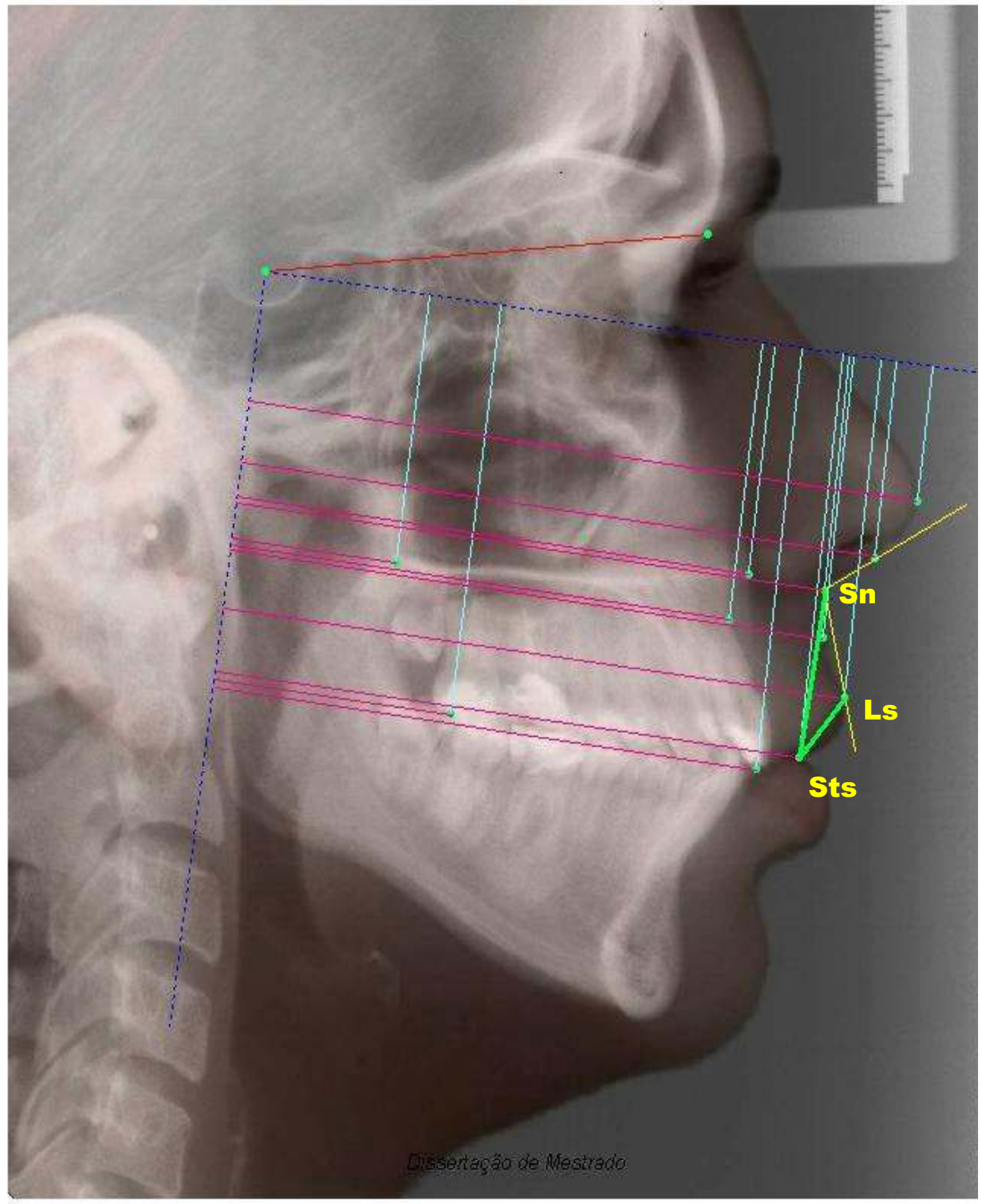

Figura 2 - Medidas em tecido duro, em tecido mole e medidas adicionais 


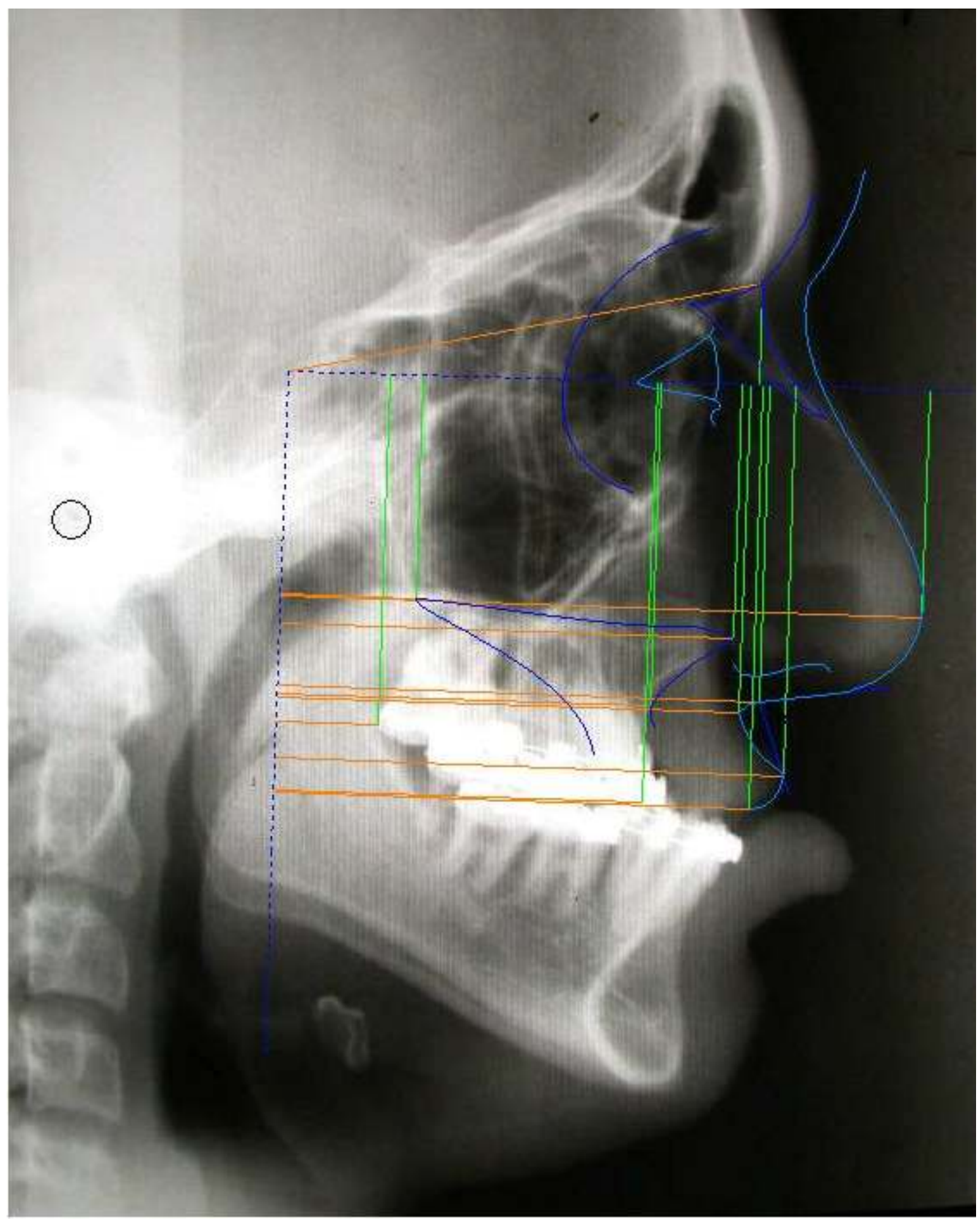

Figura 3 - Aplicação do programa Cef-X (CDT Informática Ltda - Cuiabá, MT). Radiografia pré-operatória 


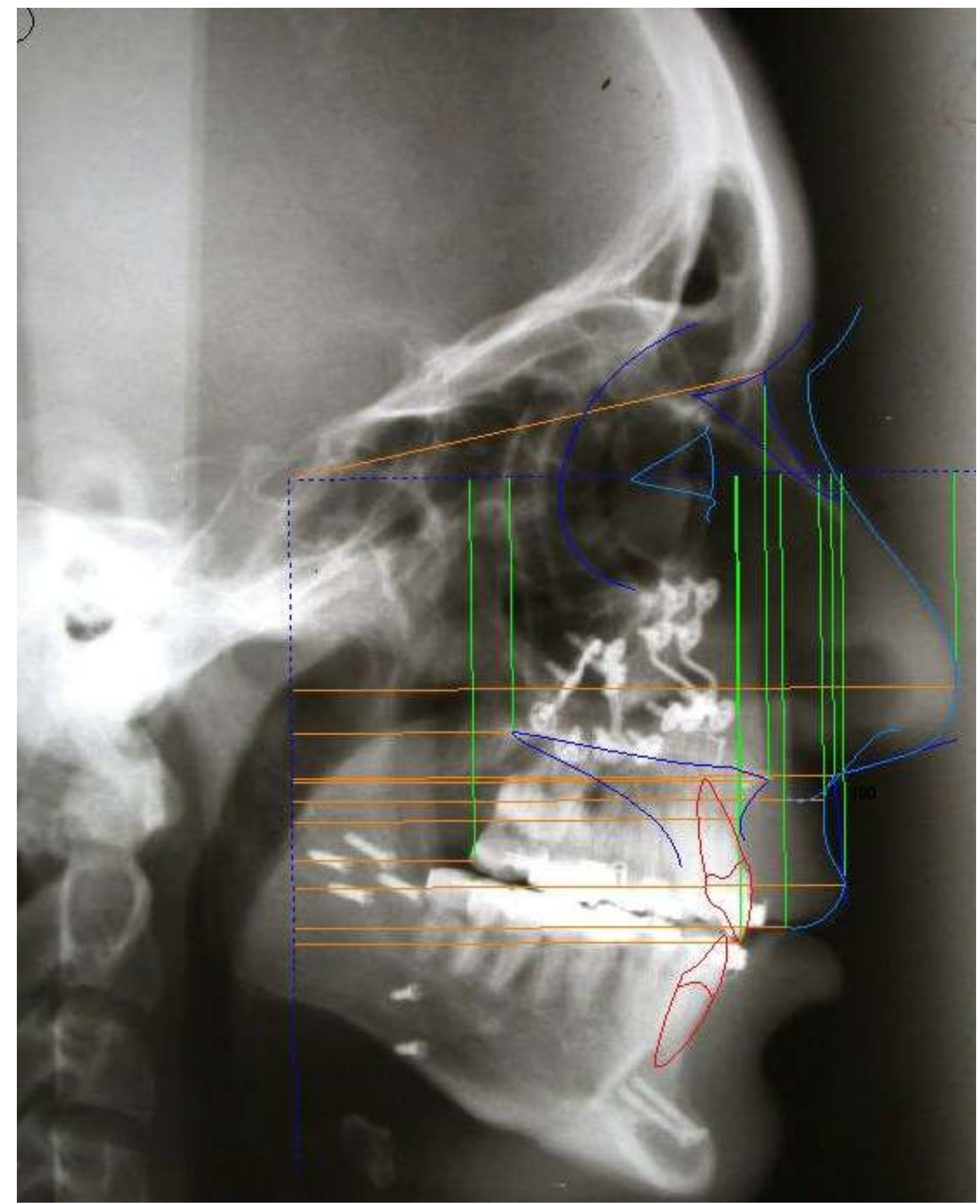

Figura 4 - Aplicação do programa Cef-X (CDT Informática Ltda. - Cuiabá, MT). Radiografia pós-operatória 


\subsection{Tratamento Estatístico}

Para este estudo, os dados coletados e tabulados em períodos pré-operatório imediato (T0) e pós-operatório mínimo de 6 meses (T1) foram submetidos à análise estatística descritiva pertinente e ao teste "t" de Student pareado, para averiguação das diferenças entre os períodos pós- operatório e pré-operatório (T1 menos T0), seguido do Modelo de Regressão Linear Múltiplo para obter a proporção da movimentação de tecidos moles associada à movimentação óssea. 
RESULTADOS 


\section{RESULTADOS}

\subsection{Análise Descritiva}

Esta amostra contém 8 pacientes do sexo feminino e 17 do sexo masculino, com idade entre 15 e 35 anos, média de 20,56 anos e mediana de 20 anos. Os perfis fotográficos e radiográficos, pré e pós-operatórios utilizados neste estudo encontram-se no Anexo 4.

\section{- Perfis cefalométricos individuais}

Os perfis cefalométricos pré e pós-cirurgia de cada um dos indivíduos (casos) podem ser vistos nas Figuras 5, 6, 7, 8, 9, 10 e 11. 

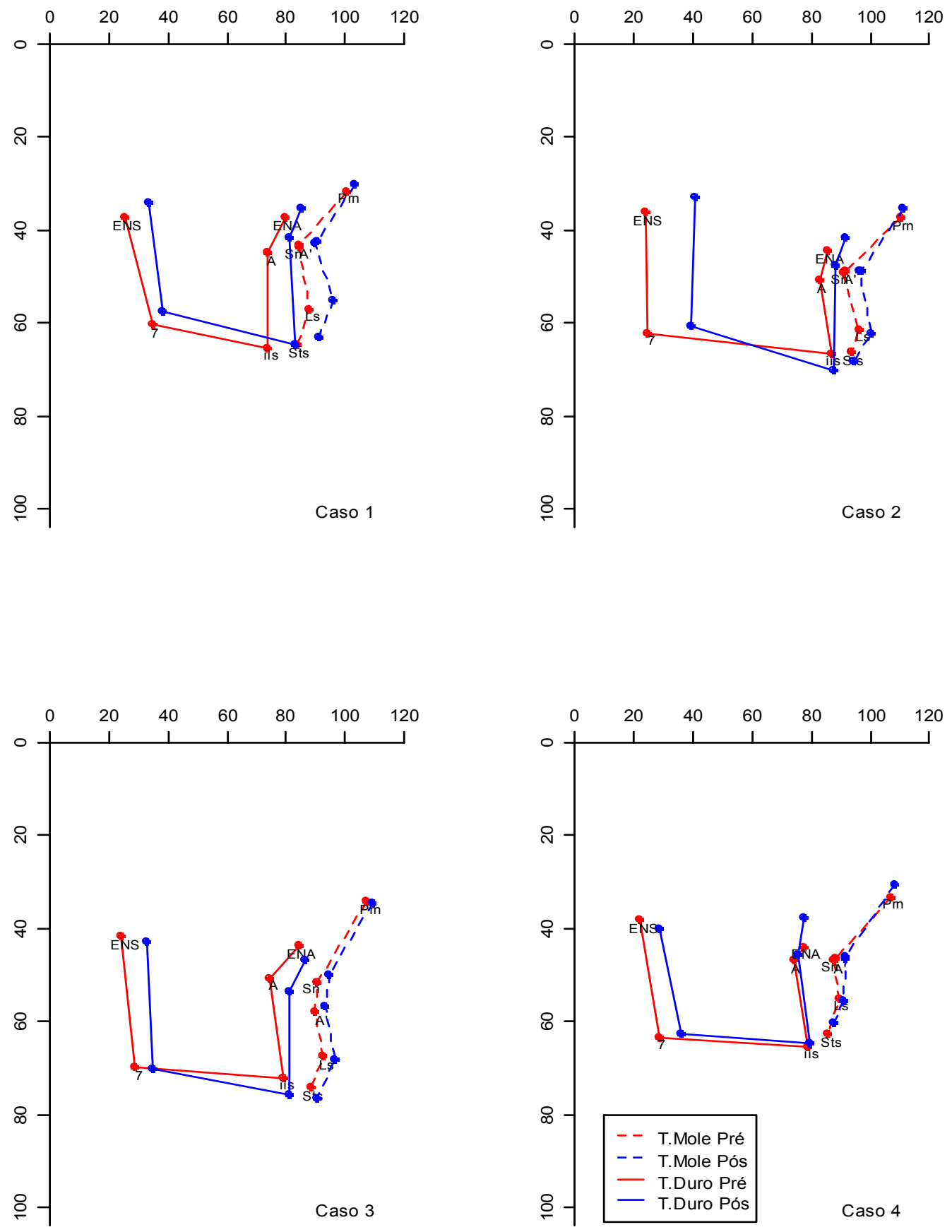

Figura 5 - Perfis cefalométricos individuais dos casos 1, 2, 3 e 4 

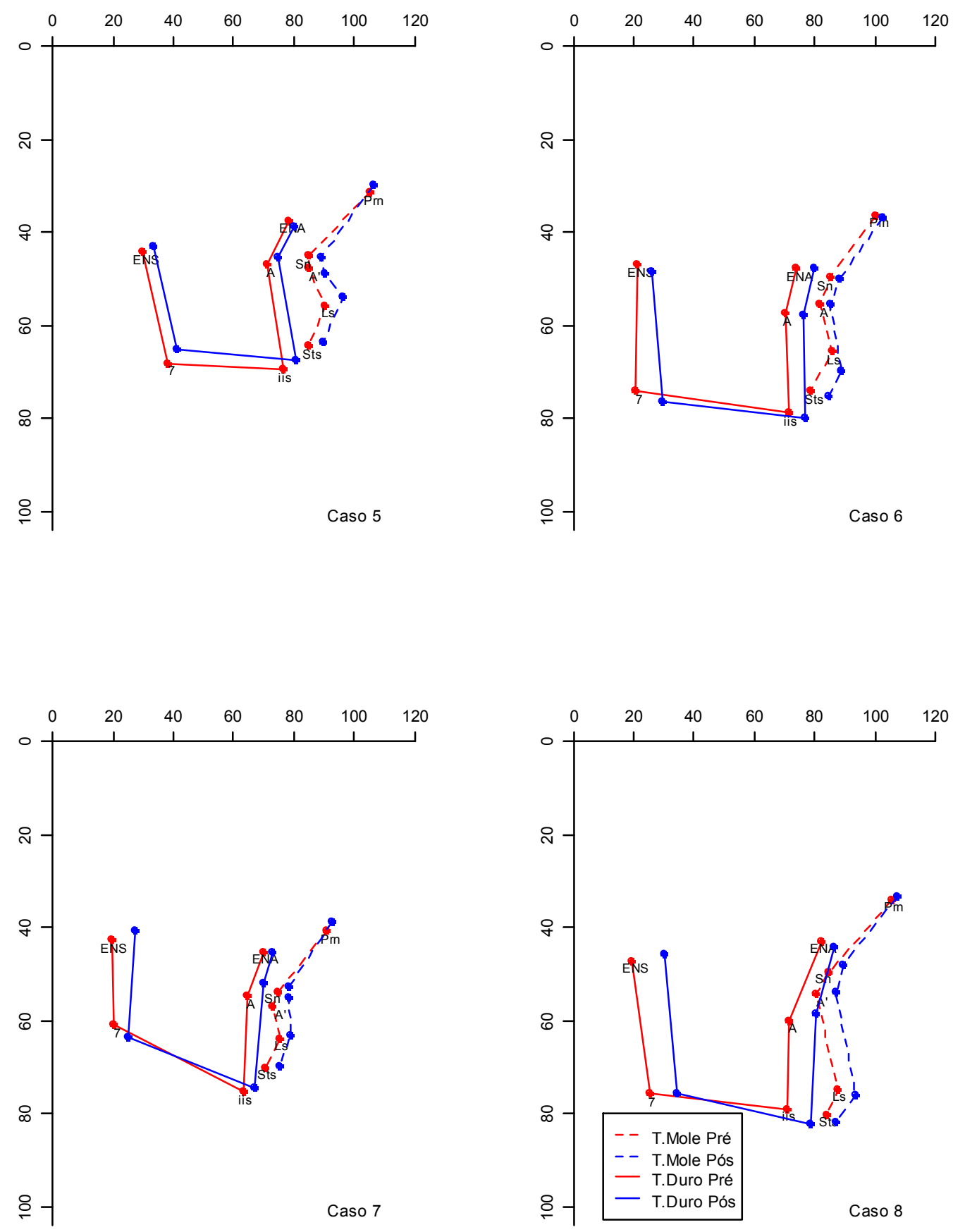

Figura 6 - Perfis cefalométricos individuais dos casos 5, 6, 7 e 8 

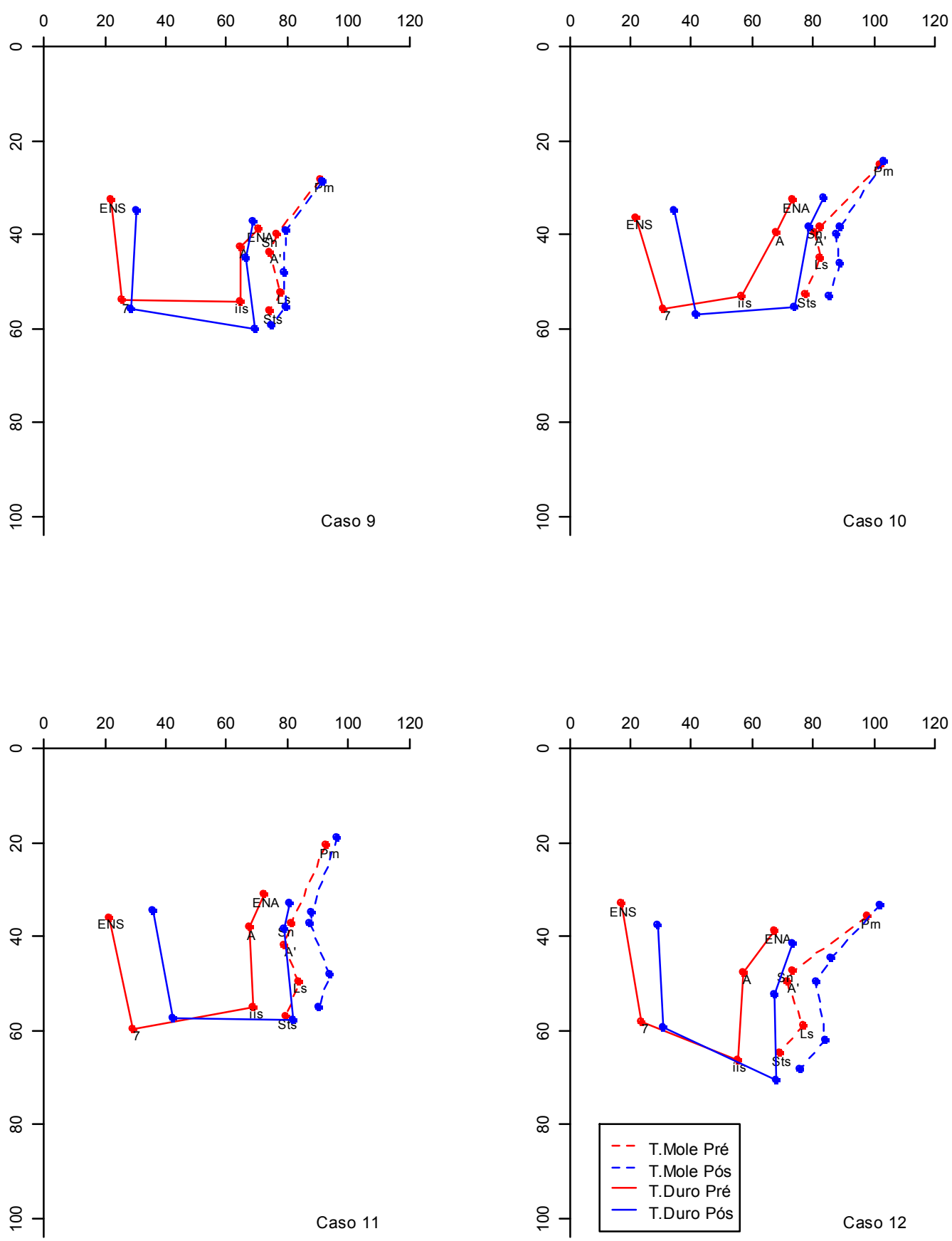

Figura 7 - Perfis cefalométricos individuais dos casos 9, 10, 11 e 12 

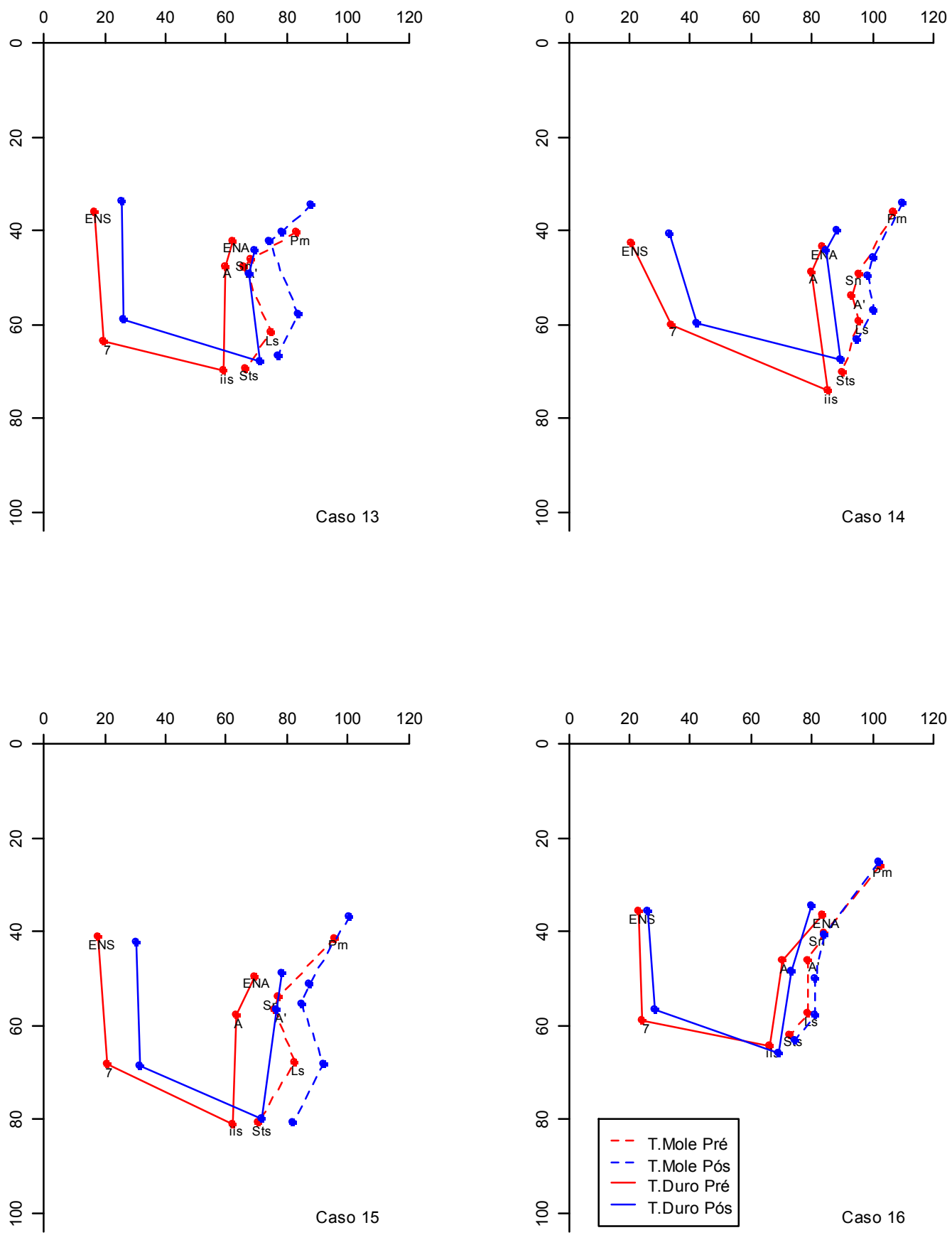

Figura 8 - Perfis cefalométricos individuais dos casos 13, 14, 15 e 16 

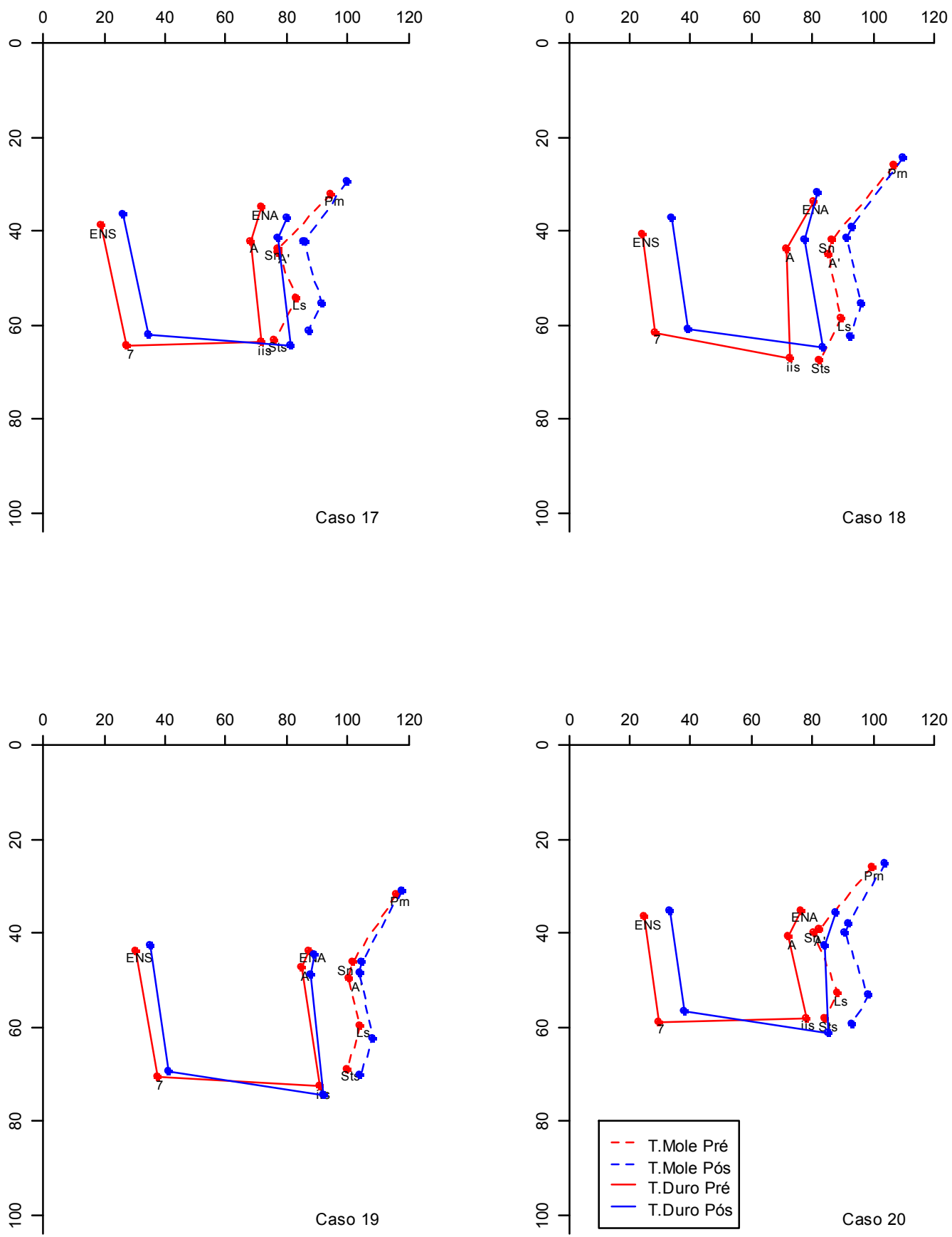

Figura 9 - Perfis cefalométricos individuais dos casos 17, 18, 19 e 20 

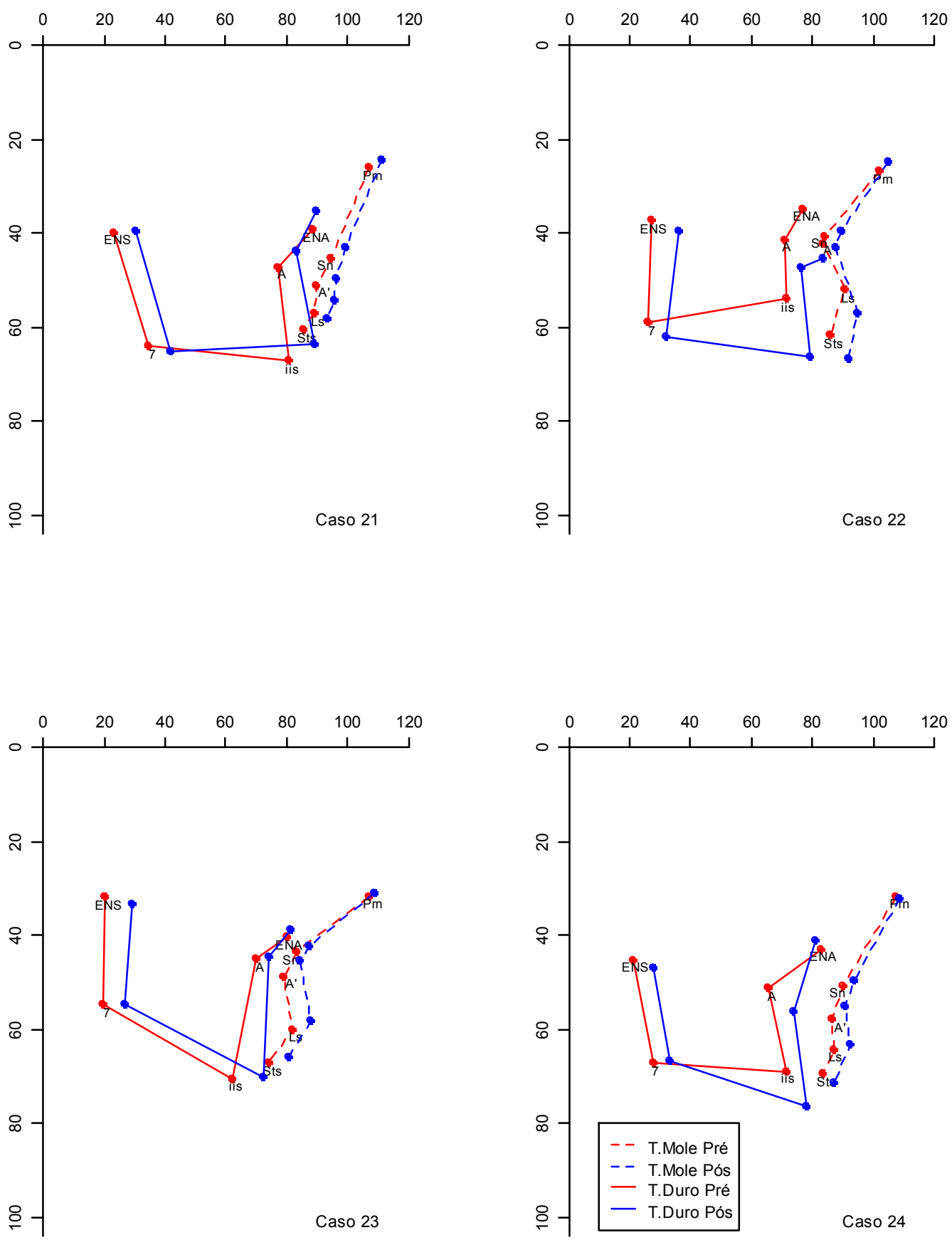

Figura 10 - Perfis cefalométricos individuais dos casos 21, 22, 23 e 24 


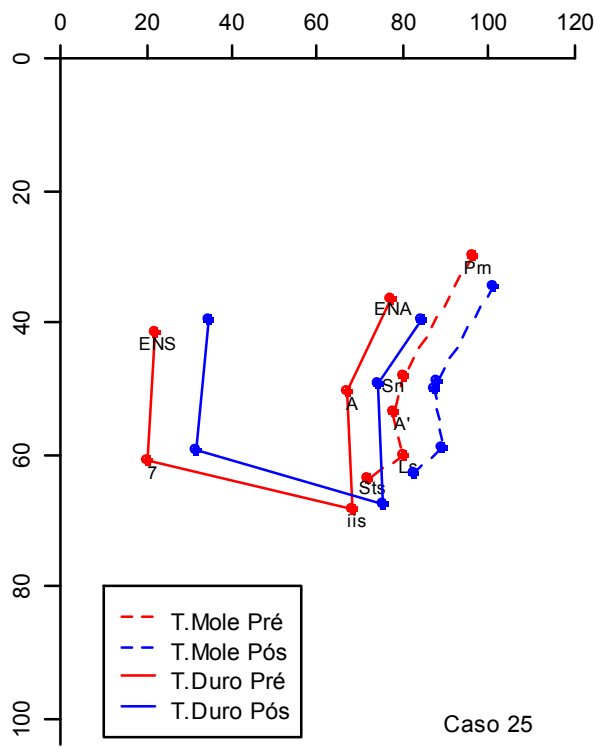

Figura 11 - Perfil cefalométrico individual do caso 25 
O que se observa na maioria dos casos é uma mudança maior na direção horizontal, tanto no tecido mole como no tecido duro.

- Tecido mole

Através da Figura 12 é possível verificar que os pontos que apresentam maior modificação no sentido vertical são: Prn, Sn e A'. Os pontos Ls e Sts apresentaram mediana próxima ao valor nulo, portanto, não há evidências de que ocorra uma modificação importante destas medidas no sentido vertical. Para melhor compreensão das figuras, observar legenda dos boxplots (Anexo 3). 

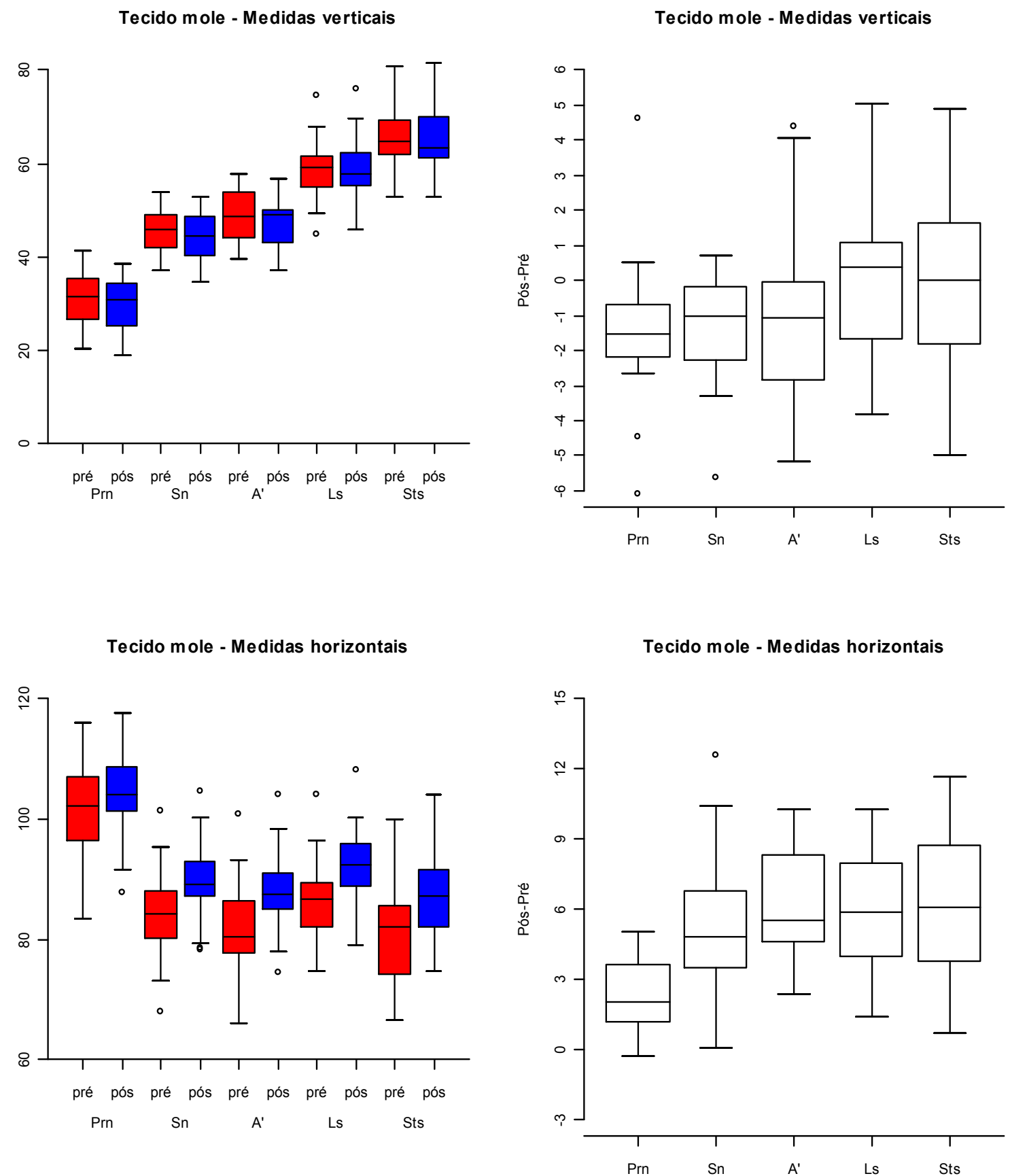

Figura 12 - Boxplots das medidas pós menos pré-operatórias, verticais e horizontais do tecido mole 
Com relação às medidas horizontais, há indícios de mudança de todos os pontos, sendo que o ponto Prn apresentou a menor mudança, bastando verificar os boxplots das diferenças.

\section{- Tecido duro}

No tecido duro, os boxplots das medidas pré e pós-operatórias e suas diferenças, para cada ponto (Figura 13), mostram que não há indício de grande mudança para as medidas verticais em todos os casos, pois as medianas destas estão próximas ao valor nulo. No entanto, nota-se indícios de diferença importante em todos os pontos das medidas horizontais. 
Tecido duro - Medidas verticais

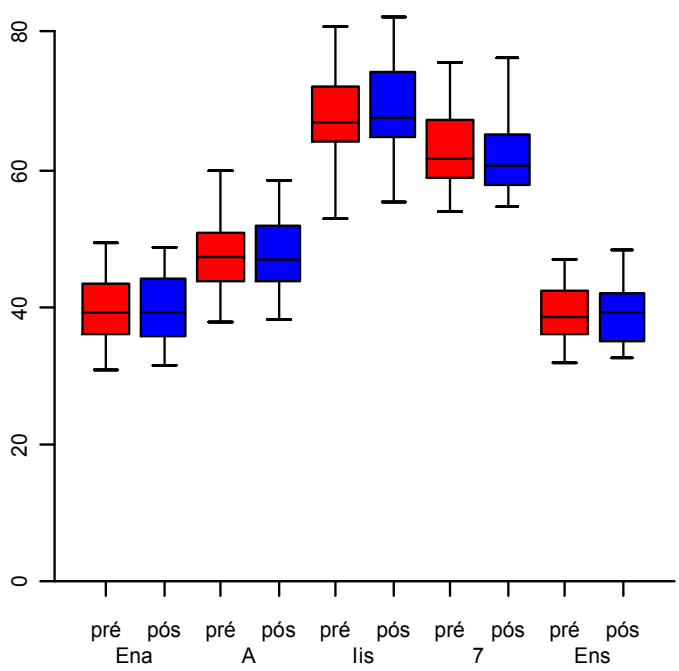

Tecido duro - Medidas horizontais

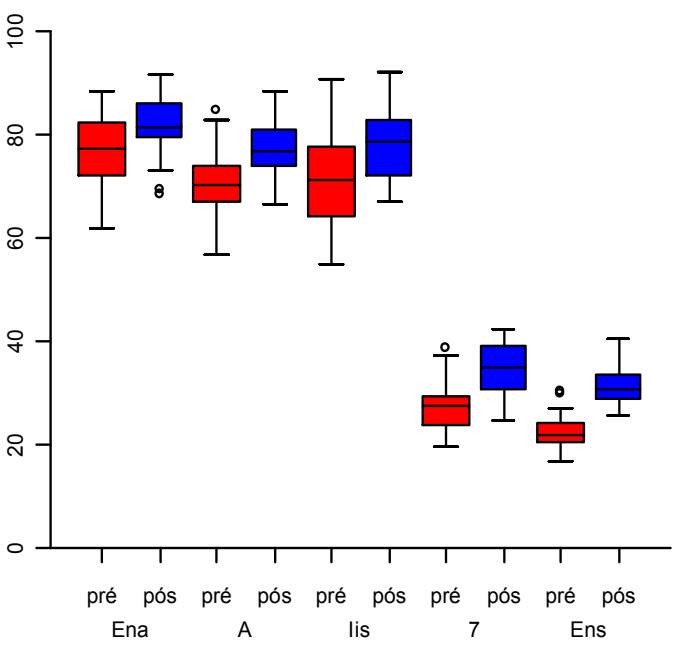

Tecido duro - Medidas verticais

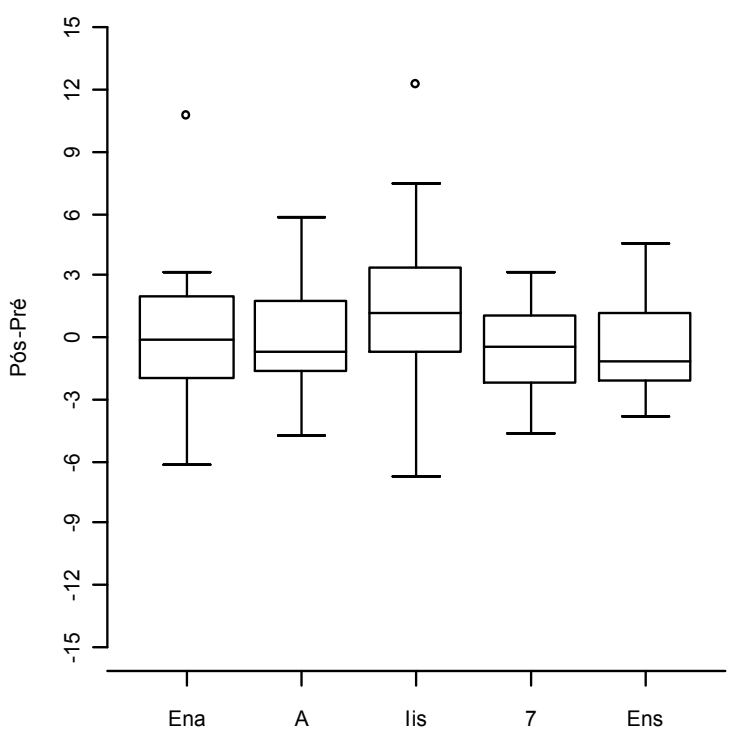

Tecido duro - Medidas horizontais

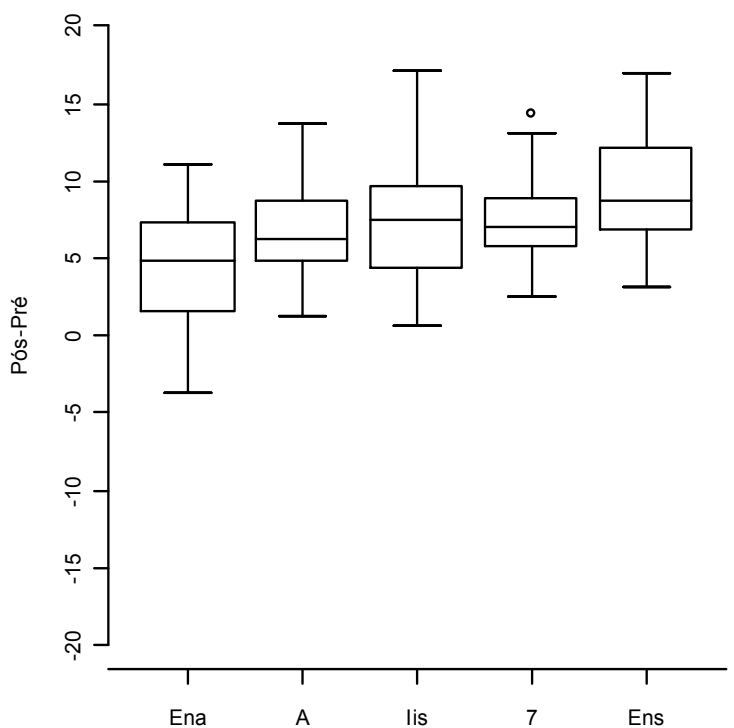

Figura 13 - Boxplots das medidas pós menos pré-operatórias, verticais e horizontais do tecido duro 
- Medidas adicionais

Através da Figura 14, é possível notar que aproximadamente $75 \%$ dos indivíduos apresentaram aumento da medida de ANL, ocorrendo o mesmo para a distância Sn-Sts. Para a medida Ls-Sts há indícios de diminuição das medidas. 

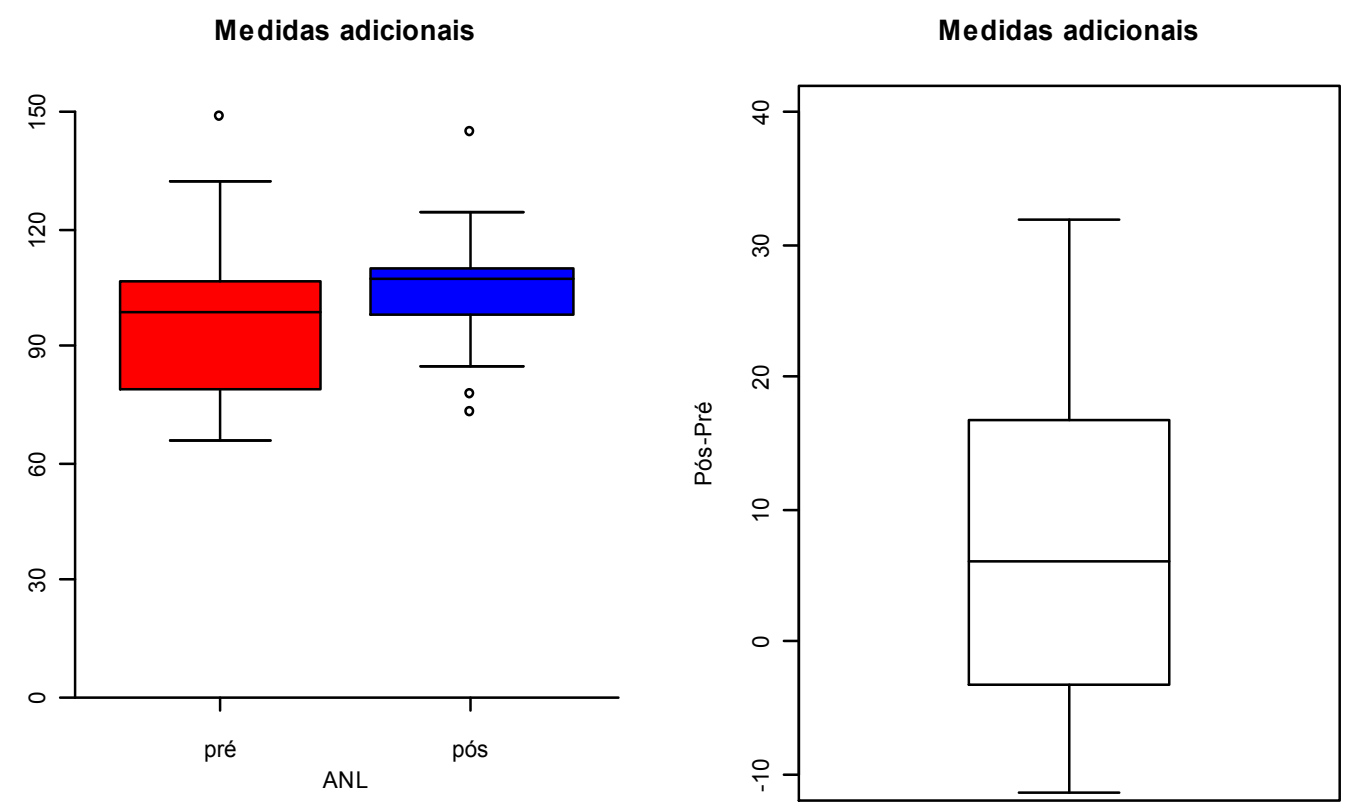

ANL

Medidas adicionais

Medidas adicionais
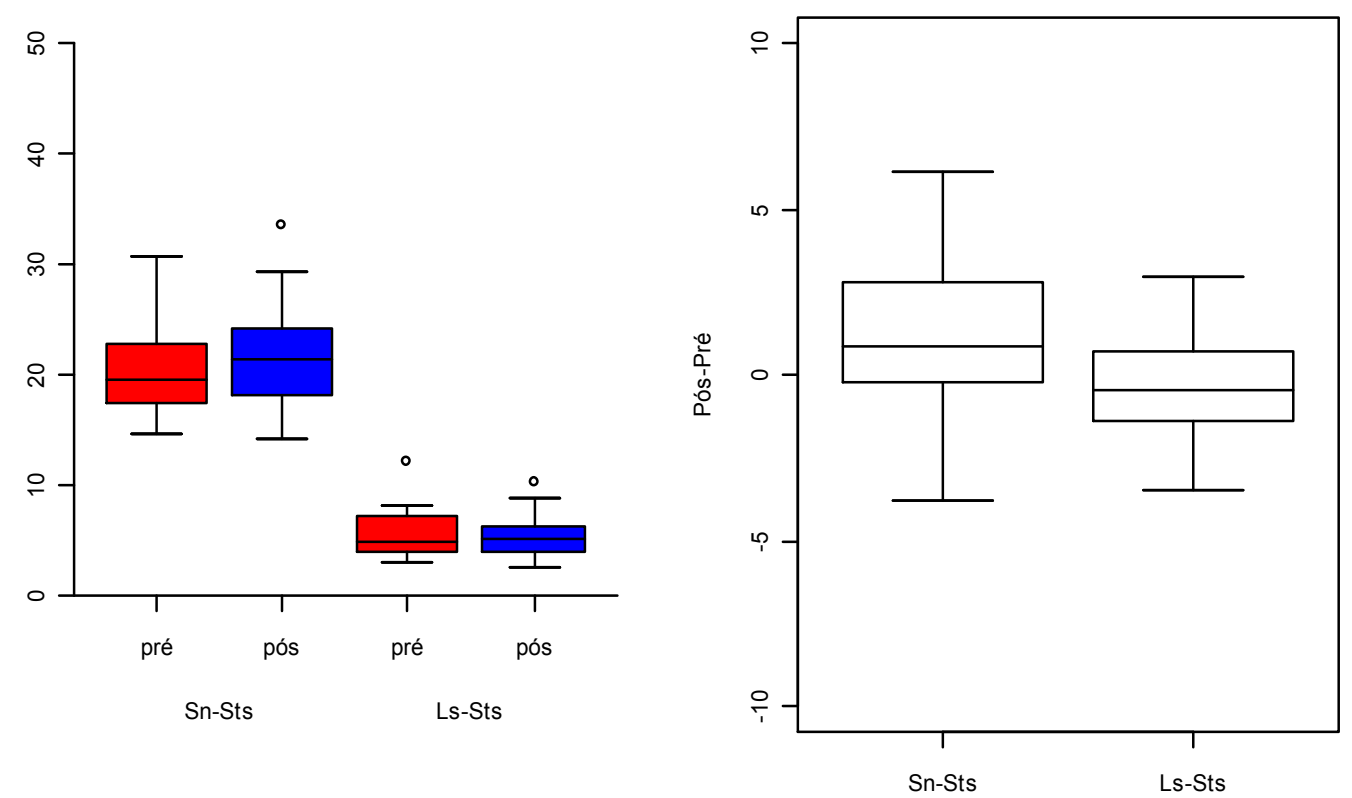

Figura 14 - Boxplots das medidas adicionais pós menos pré-operatórias 


\subsection{Análise Inferencial}

- Comparação das medidas pré e pós-operatórias

Para comparar as medidas pré e pós-operatórias, foi utilizado o teste "t" de Student pareado (Bussab e Morettin 2006). Observando as medidas-resumo nas Tabelas 1, 2 e 3 e os resultados do teste na Tabela 4, é possível notar que não ocorre diferença estatisticamente significante em relação às medidas verticais dos pontos Ls e Sts e em todas as medidas verticais dos pontos do tecido duro. Além disso, não houve diferença significante para a medida Ls-Sts. Para todas as medidas horizontais foram encontradas diferenças significantes, sendo que a menor mudança foi do ponto Prn. O perfil cefalométrico médio, de todos os pacientes da amostra, pré e pósoperatório, pode ser visto na Figura 15. 
Tabela 1 - Medidas-resumo dos pontos cefalométricos em tecido mole e duro no sentido vertical para os períodos pré-operatório, pós-operatório e a diferença entre períodos

\begin{tabular}{|c|c|c|c|c|c|c|c|}
\hline Tecido & Pontos & Período & Média & Desvio-padrão & Mínimo & Mediana & Máximo \\
\hline \multirow{15}{*}{ Mole } & \multirow{3}{*}{ Prn } & Pré & 31,7 & 5,4 & 20,5 & 31,5 & 41,2 \\
\hline & & Pós & 30,4 & 4,9 & 19,0 & 30,8 & 38,6 \\
\hline & & Pós-Pré & $-1,3$ & 1,9 & $-6,1$ & $-1,5$ & 4,6 \\
\hline & \multirow{3}{*}{ Sn } & Pré & 45,5 & 4,7 & 37,2 & 46,0 & 53,8 \\
\hline & & Pós & 44,2 & 4,9 & 34,7 & 44,4 & 52,8 \\
\hline & & Pós-Pré & $-1,3$ & 1,4 & $-5,6$ & $-1,0$ & 0,7 \\
\hline & \multirow{3}{*}{$A^{*}$} & Pré & 48,9 & 5,7 & 39,5 & 48,6 & 57,9 \\
\hline & & Pós & 47,8 & 5,6 & 37,0 & 48,9 & 56,9 \\
\hline & & Pós-Pré & $-1,1$ & 2,4 & $-5,2$ & $-1,1$ & 4,4 \\
\hline & \multirow{3}{*}{ Ls } & Pré & $\begin{array}{l}58,8 \\
\end{array}$ & 6,4 & 44,8 & 59,0 & 74,6 \\
\hline & & Pós & 59,0 & 6,8 & 45,9 & 57,9 & 76,1 \\
\hline & & Pós-Pré & 0,1 & 2,3 & $-3,8$ & 0,4 & 5,1 \\
\hline & \multirow{3}{*}{ Sts } & Pré & 65,9 & 6,9 & 52,7 & 64,9 & 80,7 \\
\hline & & Pós & 65,8 & 7,3 & 53,0 & 63,5 & 81,7 \\
\hline & & Pós-Pré & $-0,1$ & 2,7 & $-7,1$ & 0,0 & 4,9 \\
\hline \multirow{15}{*}{ Duro } & \multirow{3}{*}{ ENA } & Pré & 39,8 & 4,9 & 31,0 & 39,2 & 49,4 \\
\hline & & Pós & 39,9 & 5,0 & 31,6 & 39,3 & 48,8 \\
\hline & & Pós-Pré & 0,1 & 3,3 & $-6,2$ & $-0,1$ & 10,8 \\
\hline & \multirow{3}{*}{ A } & Pré & 47,5 & 5,7 & 38,0 & 47,1 & 59,9 \\
\hline & & Pós & 47,6 & 5,8 & 38,3 & 47,1 & 58,4 \\
\hline & & Pós-Pré & 0,0 & 2,8 & $-4,7$ & $-0,6$ & 5,9 \\
\hline & \multirow{3}{*}{ lis } & Pré & 67,1 & 7,8 & 52,9 & 67,0 & 80,8 \\
\hline & & Pós & 68,5 & 7,0 & 55,2 & 67,5 & 82,3 \\
\hline & & Pós-Pré & 1,4 & 3,9 & $-6,8$ & 1,1 & 12,3 \\
\hline & \multirow{3}{*}{7} & Pré & 62,9 & 5,7 & 54,0 & 61,5 & 75,6 \\
\hline & & Pós & 62,4 & 5,9 & 54,6 & 60,8 & 76,4 \\
\hline & & Pós-Pré & $-0,5$ & 2,0 & $-4,6$ & $-0,4$ & 3,1 \\
\hline & \multirow{3}{*}{ ENS } & Pré & 39,3 & 4,3 & 31,8 & 38,7 & 47,0 \\
\hline & & Pós & 38,8 & 4,5 & 32,8 & 39,3 & 48,5 \\
\hline & & Pós-Pré & $-0,5$ & 2,2 & $-3,9$ & $-1,2$ & 4,6 \\
\hline
\end{tabular}


Tabela 2 - Medidas-resumo dos pontos cefalométricos em tecido mole e duro no sentido horizontal para os períodos pré-operatório, pósoperatório e a diferença entre períodos

\begin{tabular}{|c|c|c|c|c|c|c|c|}
\hline Tecido & Pontos & Período & Média & Desvio-padrão & Mínimo & Mediana & Máximo \\
\hline \multirow{15}{*}{ Mole } & \multirow{3}{*}{ Prn } & Pré & 101,5 & 7,3 & 83,4 & 102,1 & 116,1 \\
\hline & & Pós & 103,9 & 6,8 & 87,8 & 104,1 & 117,6 \\
\hline & & Pós-Pré & 2,4 & 1,5 & $-0,3$ & 2,0 & 5,0 \\
\hline & \multirow{3}{*}{ Sn } & Pré & 84,0 & 7,5 & 68,0 & 84,2 & 101,5 \\
\hline & & Pós & 89,7 & 6,4 & 78,3 & 89,0 & 104,7 \\
\hline & & Pós-Pré & 5,7 & 2,9 & 0,1 & 4,8 & 12,6 \\
\hline & \multirow{3}{*}{$A^{\circ}$} & Pré & 82,0 & 7,6 & 66,0 & 80,4 & 100,8 \\
\hline & & Pós & 88,1 & 6,7 & 74,3 & 87,6 & 104,1 \\
\hline & & Pós-Pré & 6,1 & 2,3 & 2,4 & 5,6 & 10,3 \\
\hline & \multirow{3}{*}{ Ls } & Pré & 86,0 & 7,1 & 74,6 & 86,7 & 104,1 \\
\hline & & Pós & 92,0 & 7,0 & 79,2 & 92,5 & 108,2 \\
\hline & & Pós-Pré & 5,9 & 2,6 & 1,4 & 5,9 & 10,3 \\
\hline & \multirow{3}{*}{ Sts } & Pré & 80,5 & 8,2 & 66,5 & 82,1 & 99,9 \\
\hline & & Pós & 86,7 & 7,5 & 74,6 & 87,3 & 104,0 \\
\hline & & Pós-Pré & 6,2 & 3,5 & 0,7 & 6,1 & 11,7 \\
\hline \multirow{15}{*}{ Duro } & \multirow{3}{*}{ ENA } & Pré & 77,3 & 6,7 & 62,2 & 77,5 & 88,6 \\
\hline & & Pós & 81,6 & 6,0 & 68,6 & 81,4 & 91,8 \\
\hline & & Pós-Pré & 4,3 & 3,9 & $-3,7$ & 4,8 & 11,1 \\
\hline & \multirow{3}{*}{ A } & Pré & 70,4 & 6,5 & 57,1 & 70,2 & 84,9 \\
\hline & & Pós & 77,1 & 5,9 & 66,5 & 76,8 & 88,4 \\
\hline & & Pós-Pré & 6,8 & 3,2 & 1,3 & 6,2 & 13,6 \\
\hline & \multirow{3}{*}{ lis } & Pré & 71,4 & 9,2 & 55,0 & 71,3 & 90,9 \\
\hline & & Pós & 78,6 & 7,2 & 67,2 & 79,0 & 92,1 \\
\hline & & Pós-Pré & 7,2 & 4,2 & 0,6 & 7,5 & 17,1 \\
\hline & \multirow{3}{*}{7} & Pré & 27,2 & 5,5 & 19,7 & 27,4 & 38,5 \\
\hline & & Pós & 34,7 & 5,5 & 24,8 & 34,8 & 42,3 \\
\hline & & Pós-Pré & 7,5 & 3,1 & 2,5 & 7,1 & 14,3 \\
\hline & \multirow{3}{*}{ ENS } & Pré & 22,3 & 3,5 & 16,8 & 21,8 & 30,5 \\
\hline & & Pós & 31,4 & 3,8 & 25,8 & 30,6 & 40,6 \\
\hline & & Pós-Pré & 9,1 & 3,4 & 3,1 & 8,7 & 16,9 \\
\hline
\end{tabular}


Tabela 3 - Medidas-resumo das medidas adicionais para os períodos préoperatório, pós-operatório e a diferença entre períodos

\begin{tabular}{c|c|c|c|c|c|c}
\hline Medida & Período & Média & Desvio-padrão & Mínimo & Mediana & Máximo \\
\hline \multirow{4}{*}{ ANL } & Pré & 98,0 & 20,5 & 66,0 & 98,9 & 149,1 \\
& Pós & 105,1 & 15,2 & 73,1 & 107,7 & 144,9 \\
& Pós-Pré & 7,1 & 11,4 & $-11,4$ & 6,1 & 32,0 \\
\hline \multirow{3}{*}{ Sn-Sts } & Pré & 20,4 & 4,0 & 14,6 & 19,7 & 30,7 \\
& Pós & 21,6 & 4,9 & 14,2 & 21,3 & 33,6 \\
& Pós-Pré & 1,2 & 2,4 & $-3,8$ & 0,9 & 6,2 \\
\hline \multirow{3}{*}{ Ls-Sts } & Pré & 5,6 & 2,2 & 3,0 & 4,9 & 12,1 \\
& Pós & 5,3 & 1,8 & 2,7 & 5,2 & 10,2 \\
& Pós-Pré & $-0,3$ & 1,7 & $-3,5$ & $-0,4$ & 3,0 \\
\hline
\end{tabular}


Tabela 4 - Resultados dos testes-t pareados para as diferenças médias (pós menos pré-operatórias) de todos os pontos e medidas adicionais

\begin{tabular}{|c|c|c|c|c|c|c|}
\hline \multirow{2}{*}{ Variáveis } & \multirow{2}{*}{ Tecido } & \multirow{2}{*}{ Pontos } & \multirow{2}{*}{$\begin{array}{c}\text { Diferença média } \\
\text { (pós-pré) }\end{array}$} & \multirow{2}{*}{$p$} & \multicolumn{2}{|c|}{ Intervalo de confiança(95\%) } \\
\hline & & & & & Limite inferior & Limite superior \\
\hline \multirow{10}{*}{ Verticais } & \multirow{5}{*}{ Mole } & Prn & $-1,32$ & 0,002 & $-2,12$ & $-0,53$ \\
\hline & & Sn & $-1,30$ & 0,000 & $-1,89$ & $-0,71$ \\
\hline & & $A^{\prime}$ & $-1,13$ & 0,026 & $-2,11$ & $-0,15$ \\
\hline & & Ls & 0,13 & 0,775 & $-0,82$ & 1,09 \\
\hline & & Sts & $-0,13$ & 0,813 & $-1,23$ & 0,98 \\
\hline & \multirow{5}{*}{ Duro } & ENA & 0,06 & 0,928 & $-1,30$ & 1,42 \\
\hline & & $\mathrm{A}$ & 0,04 & 0,945 & $-1,10$ & 1,18 \\
\hline & & lis & 1,36 & 0,091 & $-0,24$ & 2,96 \\
\hline & & 7 & $-0,48$ & 0,237 & $-1,30$ & 0,34 \\
\hline & & ENS & $-0,48$ & 0,282 & $-1,38$ & 0,42 \\
\hline \multirow{10}{*}{ Horizontais } & \multirow{5}{*}{ Mole } & Prn & 2,44 & 0,000 & 1,81 & 3,07 \\
\hline & & Sn & 5,67 & 0,000 & 4,48 & 6,87 \\
\hline & & $A^{\prime}$ & 6,10 & 0,000 & 5,17 & 7,03 \\
\hline & & Ls & 5,92 & 0,000 & 4,83 & 7,02 \\
\hline & & Sts & 6,23 & 0,000 & 4,81 & 7,66 \\
\hline & \multirow{5}{*}{ Duro } & ENA & 4,28 & 0,000 & 2,68 & 5,89 \\
\hline & & $A$ & 6,75 & 0,000 & 5,41 & 8,09 \\
\hline & & lis & 7,23 & 0,000 & 5,50 & 8,96 \\
\hline & & 7 & 7,47 & 0,000 & 6,18 & 8,76 \\
\hline & & ENS & 9,08 & 0,000 & 7,67 & 10,49 \\
\hline \multirow{3}{*}{\multicolumn{2}{|c|}{ Adicionais }} & ANL & 7,06 & 0,005 & 2,34 & 11,78 \\
\hline & & Sn-Sts & 1,17 & 0,025 & 0,16 & 2,17 \\
\hline & & Ls-Sts & $-0,31$ & 0,370 & $-1,00$ & 0,39 \\
\hline
\end{tabular}

- Diferença estatisticamente significante em negrito $(p<0,05)$ 
Perfil médio

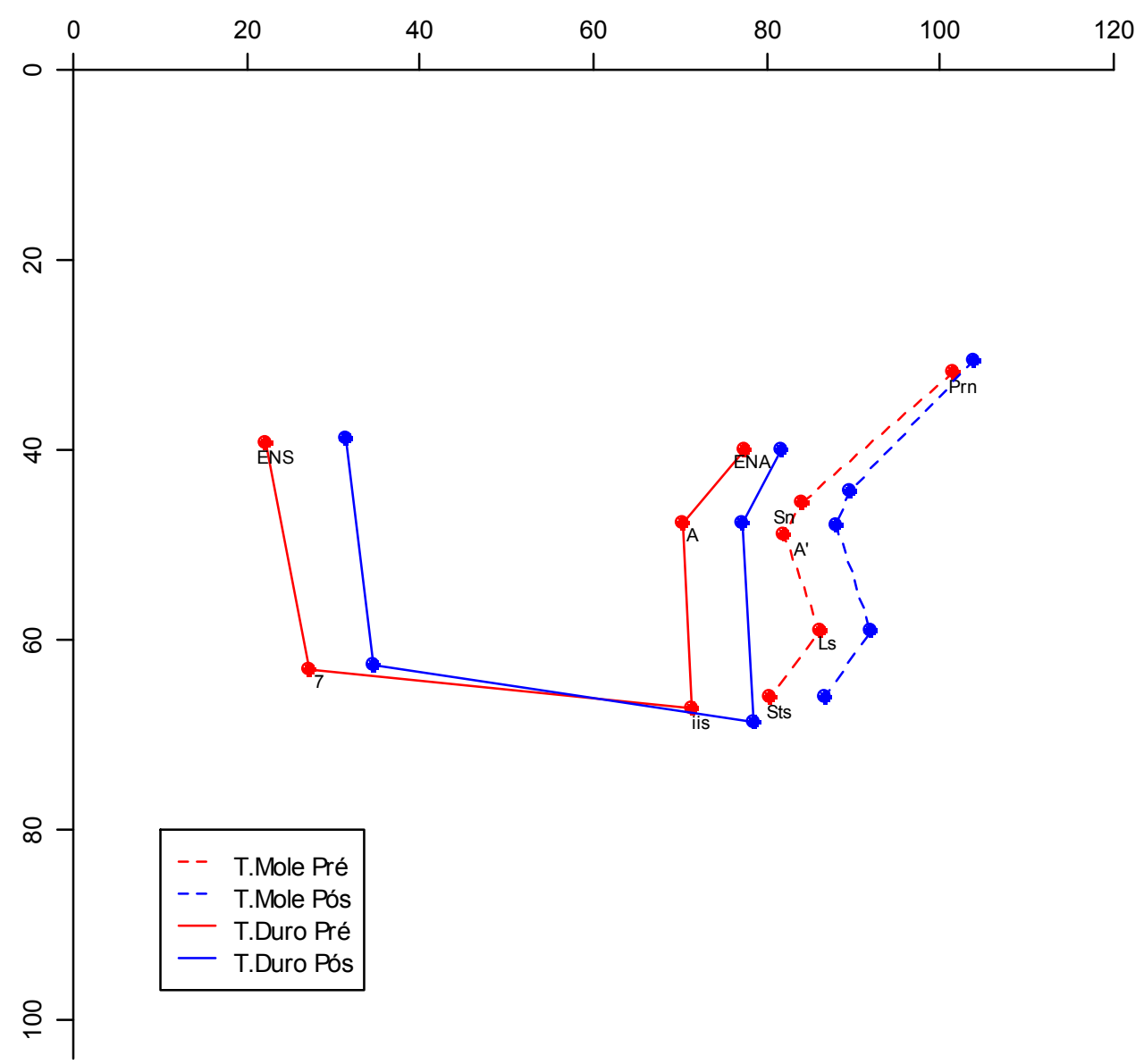

Figura 15 - Perfil cefalométrico médio das medidas pré e pós-operatórias, de todos os pacientes da amostra $(n=25)$ 


\section{- Associação entre as medidas em tecido mole e em tecido duro}

Para cada um dos pontos do tecido mole (Prn, Sn, A', Ls e Sts), bem como para as medidas adicionais Sn-Sts e Ls-Sts e para a medida angular (ANL), utilizou-se um Modelo de Regressão Linear Múltiplo (Neter et al 1996). A diferença das medidas pós e pré-operatórias foi considerada como variável resposta, no sentido vertical e horizontal de cada medida citada anteriormente. Como variáveis independentes foram utilizadas as diferenças das medidas pós e pré-operatórias, também no sentido vertical e horizontal, dos pontos de tecido duro: ENA, lis, 7 e ENS. As medidas vertical e horizontal referentes ao ponto $A$ foram desconsideradas, em virtude de problemas de multicolinearidade com os pontos lis (medida vertical) e ENA (medida horizontal).

Tomando como base a interpretação do sentido (horizontal ou vertical) e direção das variáveis independentes (fatores), segundo as médias "pós-pré" das Tabelas 1, 2 e 3, obtêm-se como respostas as proporções (coeficientes) significantes, em média, indicadas pelos modelos de regressão:

- Prn (diferença pós e pré-operatória):Tabela 5;

- Sn (diferença pós e pré-operatória): Tabela 6;

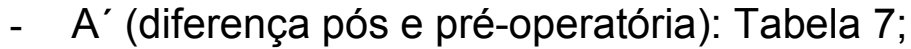

- Ls (diferença pós e pré-operatória): Tabela 8;

- $\quad$ Sts (diferença pós e pré-operatória): Tabela 9;

- Sn-Sts (diferença pós e pré-operatória): Tabela 10;

- Ls-Sts (diferença pós e pré-operatória): Tabela 11;

- $\quad$ ANL (diferença pós e pré-operatória): Tabela 12. 
$\mathrm{Na}$ Tabela 5, quando da movimentação inferior de lis tem-se, em média, 20\% de movimentação posterior do ponto Prn.

Tabela 5 - Associação entre todas as medidas em tecido duro (fatores) e o ponto Prn (variável resposta). Os coeficientes obtidos demonstram, em média, as proporções de movimentação de Prn em relação à movimentação do tecido duro

\begin{tabular}{c|l|c|c|c|c}
\hline V. resposta & Fatores & Coeficiente & Erro-padrão & $\mathrm{t}$ & $p$ \\
\hline & Intercepto & $-1,05$ & 1,42 & $-0,74$ & 0,470 \\
& ENA-LHR & 0,11 & 0,21 & 0,53 & 0,607 \\
& ENA-LVR & $-0,19$ & 0,19 & $-0,98$ & 0,344 \\
Prn-LHR & lis-LHR & 0,07 & 0,17 & 0,44 & 0,667 \\
& lis-LVR & $-0,05$ & 0,13 & $-0,38$ & 0,708 \\
& 7-LHR & 0,16 & 0,27 & 0,57 & 0,579 \\
& 7-LVR & 0,24 & 0,24 & 1,00 & 0,334 \\
& ENS-LHR & $-0,16$ & 0,29 & $-0,55$ & 0,587 \\
& ENS-LVR & $-0,12$ & 0,21 & $-0,54$ & 0,594 \\
\hline \multirow{5}{*}{ Prn-LVR } & Intercepto & 1,18 & 0,73 & 1,62 & 0,125 \\
& ENA-LHR & 0,18 & 0,11 & 1,70 & 0,109 \\
& ENA-LVR & 0,18 & 0,10 & 1,87 & 0,080 \\
& Iis-LHR & $-0,20$ & 0,09 & $-2,34$ & 0,033 \\
& lis-LVR & 0,04 & 0,06 & 0,61 & 0,548 \\
& 7-LHR & $-0,15$ & 0,14 & $-1,04$ & 0,314 \\
& 7-LVR & 0,08 & 0,13 & 0,67 & 0,512 \\
& ENS-LHR & 0,20 & 0,15 & 1,37 & 0,190 \\
& ENS-LVR & $-0,02$ & 0,11 & $-0,15$ & 0,884 \\
\hline
\end{tabular}

-Associação estatisticamente significante em negrito $(p<0,05)$

Na Tabela 6, quando da movimentação anterior de ENA tem-se, em média, 39\% de movimentação anterior do ponto Sn. Quando da movimentação superior de 7 tem-se, em média, 51\% de movimentação anterior do ponto Sn e quando da movimentação superior de ENS tem-se, em média, $60 \%$ de movimentação posterior do ponto Sn. 
Tabela 6 - Associação entre todas as medidas em tecido duro (fatores) e o ponto Sn (variável resposta). Os coeficientes obtidos demonstram, em média, as proporções de movimentação de Sn em relação à movimentação do tecido duro

\begin{tabular}{c|l|c|c|c|c}
\hline V. resposta & Fatores & Coeficiente & Erro-padrão & $\mathrm{T}$ & $p$ \\
\hline \multirow{5}{*}{ Sn-LHR } & Intercepto & 0,20 & 0,91 & 0,22 & 0,828 \\
& ENA-LHR & $-0,12$ & 0,13 & $-0,88$ & 0,390 \\
& ENA-LVR & 0,08 & 0,12 & 0,64 & 0,529 \\
& lis-LHR & 0,20 & 0,11 & 1,84 & 0,085 \\
& lis-LVR & $-0,12$ & 0,08 & $-1,47$ & 0,162 \\
& 7-LHR & 0,17 & 0,18 & 0,97 & 0,346 \\
& 7-LVR & 0,08 & 0,16 & 0,53 & 0,603 \\
& ENS-LHR & $-0,18$ & 0,18 & $-0,99$ & 0,336 \\
& ENS-LVR & $-0,21$ & 0,14 & $-1,51$ & 0,151 \\
\hline \multirow{5}{*}{ Sn-LVR } & Intercepto & 1,23 & 1,17 & 1,05 & 0,308 \\
& ENA-LHR & 0,11 & 0,17 & 0,67 & 0,513 \\
& ENA-LVR & 0,39 & 0,16 & 2,46 & $\mathbf{0 , 0 2 6}$ \\
& Iis-LHR & $-0,18$ & 0,14 & $-1,32$ & 0,206 \\
& Iis-LVR & 0,16 & 0,10 & 1,59 & 0,132 \\
& 7-LHR & $-0,51$ & 0,23 & $-2,27$ & $\mathbf{0 , 0 3 7}$ \\
& 7-LVR & $-0,12$ & 0,20 & $-0,58$ & 0,571 \\
& ENS-LHR & 0,60 & 0,24 & 2,54 & $\mathbf{0 , 0 2 2}$ \\
& ENS-LVR & 0,30 & 0,18 & 1,74 & 0,102 \\
\hline
\end{tabular}

-Associação estatisticamente significante em negrito $(p<0,05)$

Na Tabela 7, quando da movimentação inferior de lis tem-se, em média, 36\% de movimentação inferior do ponto A'. Quando da movimentação anterior de ENA tem-se, em média, $28 \%$ de movimento anterior do ponto A'. Quando da movimentação anterior de lis tem-se, em média, $17 \%$ de movimentação anterior do ponto A'. 
Tabela 7 - Associação entre todas as medidas em tecido duro (fatores) e o ponto A' (variável resposta). Os coeficientes obtidos demonstram, em média, as proporções de movimentação de $A^{\prime}$ em relação à movimentação do tecido duro

\begin{tabular}{c|l|c|c|c|c}
\hline V. resposta & Fatores & Coeficiente & Erro-padrão & $\mathrm{t}$ & $p$ \\
\hline \multirow{6}{*}{$A^{\prime}$-LHR } & Intercepto & 1,43 & 1,41 & 1,02 & 0,324 \\
& ENA-LHR & $-0,29$ & 0,21 & $-1,39$ & 0,182 \\
& ENA-LVR & 0,14 & 0,19 & 0,73 & 0,473 \\
& lis-LHR & 0,36 & 0,17 & 2,18 & $\mathbf{0 , 0 4 4}$ \\
& lis-LVR & $-0,10$ & 0,12 & $-0,83$ & 0,419 \\
& 7-LHR & 0,13 & 0,27 & 0,48 & 0,638 \\
& 7-LVR & $-0,31$ & 0,24 & $-1,30$ & 0,210 \\
& ENS-LHR & 0,04 & 0,28 & 0,16 & 0,877 \\
& ENS-LVR & $-0,05$ & 0,21 & $-0,24$ & 0,815 \\
\hline & Intercepto & 2,45 & 0,91 & 2,71 & 0,016 \\
& ENA-LHR & 0,05 & 0,13 & 0,35 & 0,728 \\
& ENA-LVR & 0,28 & 0,12 & 2,33 & $\mathbf{0 , 0 3 3}$ \\
& Iis-LHR & $-0,12$ & 0,11 & $-1,13$ & 0,274 \\
A $^{\prime}$-LVR & Iis-LVR & 0,17 & 0,08 & 2,14 & $\mathbf{0 , 0 4 8}$ \\
& 7-LHR & $-0,32$ & 0,17 & $-1,81$ & 0,089 \\
& 7-LVR & $-0,04$ & 0,16 & $-0,25$ & 0,806 \\
& ENS-LHR & 0,27 & 0,18 & 1,47 & 0,162 \\
& ENS-LVR & 0,18 & 0,14 & 1,32 & 0,205 \\
\hline
\end{tabular}

-Associação estatisticamente significante em negrito $(p<0,05)$

Na Tabela 8, quando da movimentação anterior de ENA tem-se, em média, $30 \%$ de movimentação inferior do ponto Ls. Quando da movimentação inferior de lis tem-se, em média, 33\% de movimentação inferior do ponto Ls. Quando da movimentação anterior de lis tem-se, em média, 20\% de movimentação superior do ponto Ls. Quando da movimentação anterior de lis tem-se, em média, $28 \%$ de movimentação anterior do ponto Ls e quando da movimentação superior de 7 tem-se, em média, 48\% de movimentação anterior do ponto Ls. 
Tabela 8 - Associação entre todas as medidas em tecido duro (fatores) e o ponto Ls (variável resposta). Os coeficientes obtidos demonstram, em média, as proporções de movimentação de Ls em relação à movimentação do tecido duro

\begin{tabular}{c|l|c|c|c|c}
\hline V. resposta & Fatores & Coeficiente & Erro-padrão & $\mathrm{t}$ & $p$ \\
\hline & Intercepto & 1,58 & 0,88 & 1,80 & 0,091 \\
& ENA-LHR & $-0,04$ & 0,13 & $-0,34$ & 0,741 \\
& ENA-LVR & 0,30 & 0,12 & 2,57 & $\mathbf{0 , 0 2 1}$ \\
Ls-LHR & lis-LHR & 0,33 & 0,10 & 3,23 & $\mathbf{0 , 0 0 5}$ \\
& lis-LVR & $-0,20$ & 0,08 & $-2,55$ & $\mathbf{0 , 0 2 1}$ \\
& 7-LHR & 0,34 & 0,17 & 2,03 & 0,060 \\
& 7-LVR & 0,01 & 0,15 & 0,04 & 0,968 \\
& ENS-LHR & 0,23 & 0,18 & 1,30 & 0,211 \\
& ENS-LVR & $-0,17$ & 0,13 & $-1,29$ & 0,215 \\
\hline & Intercepto & 2,22 & 0,97 & 2,27 & 0,037 \\
& ENA-LHR & 0,10 & 0,14 & 0,74 & 0,471 \\
& ENA-LVR & 0,25 & 0,13 & 1,94 & 0,070 \\
& Iis-LHR & $-0,10$ & 0,11 & $-0,83$ & 0,417 \\
Ls-LVR & Iis-LVR & 0,28 & 0,09 & 3,27 & $\mathbf{0 , 0 0 5}$ \\
& 7-LHR & $-0,48$ & 0,19 & $-2,54$ & $\mathbf{0 , 0 2 2}$ \\
& 7-LVR & 0,06 & 0,17 & 0,38 & 0,709 \\
& ENS-LHR & 0,09 & 0,20 & 0,44 & 0,664 \\
& ENS-LVR & 0,01 & 0,15 & 0,05 & 0,963 \\
\hline
\end{tabular}

-Associação estatisticamente significante em negrito $(p<0,05)$

Na Tabela 9, quando da movimentação inferior de lis tem-se, em média, 53\% de movimentação inferior do ponto Sts. Quando da movimentação inferior de lis tem-se, em média, 36\% de movimentação posterior do ponto Sts e quando da movimentação anterior de lis tem-se, em média, $44 \%$ de movimentação anterior do ponto Sts. 
Tabela 9 - Associação entre todas as medidas em tecido duro (fatores) e o ponto Sts (variável resposta). Os coeficientes obtidos demonstram, em média, as proporções de movimentação de Sts em relação à movimentação do tecido duro

\begin{tabular}{c|l|c|c|c|c}
\hline V. resposta & Fatores & Coeficiente & Erro-padrão & $\mathrm{t}$ & $p$ \\
\hline & Intercepto & 0,65 & 0,94 & 0,69 & 0,499 \\
& ENA-LHR & $-0,01$ & 0,14 & $-0,08$ & 0,940 \\
& ENA-LVR & 0,14 & 0,13 & 1,13 & 0,277 \\
Sts-LHR & lis-LHR & 0,53 & 0,11 & 4,76 & $\mathbf{0 , 0 0 0}$ \\
& lis-LVR & $-0,12$ & 0,08 & $-1,40$ & 0,182 \\
& 7-LHR & 0,09 & 0,18 & 0,51 & 0,616 \\
& 7-LVR & $-0,14$ & 0,16 & $-0,87$ & 0,399 \\
& ENS-LHR & 0,20 & 0,19 & 1,03 & 0,317 \\
& ENS-LVR & $-0,01$ & 0,14 & $-0,07$ & 0,945 \\
\hline & Intercepto & 2,78 & 1,12 & 2,48 & 0,025 \\
& ENA-LHR & 0,35 & 0,16 & 2,11 & 0,051 \\
& ENA-LVR & 0,22 & 0,15 & 1,44 & 0,168 \\
& Iis-LHR & $-0,36$ & 0,13 & $-2,75$ & $\mathbf{0 , 0 1 4}$ \\
Sts-LVR & Iis-LVR & 0,44 & 0,10 & 4,51 & $\mathbf{0 , 0 0 0}$ \\
& 7-LHR & $-0,19$ & 0,22 & $-0,88$ & 0,392 \\
& 7-LVR & 0,36 & 0,19 & 1,86 & 0,082 \\
& ENS-LHR & 0,02 & 0,23 & 0,10 & 0,919 \\
& ENS-LVR & $-0,33$ & 0,17 & $-1,95$ & 0,069 \\
\hline
\end{tabular}

-Associação estatisticamente significante em negrito $(p<0,05)$

Na Tabela 10, quando da movimentação inferior de lis tem-se, em média, 33\% de aumento da medida Sn-Sts. 
Tabela 10 - Associação entre todas as medidas em tecido duro (fatores) e o ponto Sn-Sts (variável resposta). Os coeficientes obtidos demonstram, em média, as proporções de comprimento de Sn-Sts em relação à movimentação do tecido duro

\begin{tabular}{c|l|c|c|c|c}
\hline V. resposta & Fatores & Coeficiente & Erro-padrão & $\mathrm{t}$ & $p$ \\
\hline \multirow{6}{*}{ Sn-Sts } & Intercepto & 0,46 & 1,02 & 0,46 & 0,655 \\
& ENA-LHR & 0,11 & 0,15 & 0,71 & 0,488 \\
& ENA-LVR & 0,07 & 0,14 & 0,48 & 0,639 \\
& lis-LHR & 0,33 & 0,12 & 2,74 & $\mathbf{0 , 0 1 5}$ \\
& lis-LVR & 0,00 & 0,09 & 0,02 & 0,981 \\
& 7-LHR & $-0,08$ & 0,20 & $-0,40$ & 0,697 \\
& 7-LVR & $-0,23$ & 0,17 & $-1,29$ & 0,216 \\
& ENS-LHR & 0,38 & 0,21 & 1,84 & 0,084 \\
& ENS-LVR & 0,20 & 0,15 & 1,28 & 0,218 \\
\hline
\end{tabular}

-Associação estatisticamente significante em negrito $(p<0,05)$

Na Tabela 11, quando da movimentação inferior de lis tem-se, em média, 27\% de aumento da medida Ls-Sts. Quando da movimentação anterior de lis tem-se, em média, $16 \%$ de diminuição da medida Ls-Sts e quando da movimentação anterior de ENS tem-se, em média, 33\% de aumento da medida Ls-Sts. 
Tabela 11 - Associação entre todas as medidas em tecido duro (fatores) e o ponto Ls-Sts (variável resposta). Os coeficientes obtidos demonstram, em média, as proporções de comprimento de Ls-Sts em relação à movimentação do tecido duro

\begin{tabular}{c|l|c|c|c|c}
\hline V. resposta & Fatores & Coeficiente & Erro-padrão & T & $p$ \\
\hline \multirow{6}{*}{ Ls-Sts } & Intercepto & $-0,56$ & 0,85 & $-0,66$ & 0,519 \\
& ENA-LHR & $-0,24$ & 0,12 & $-1,93$ & 0,071 \\
& ENA-LVR & 0,03 & 0,11 & 0,30 & 0,765 \\
& lis-LHR & 0,27 & 0,10 & 2,67 & $\mathbf{0 , 0 1 7}$ \\
& lis-LVR & $-0,16$ & 0,07 & $-2,20$ & $\mathbf{0 , 0 4 2}$ \\
& 7-LHR & $-0,29$ & 0,16 & $-1,75$ & 0,100 \\
& 7-LVR & $-0,29$ & 0,15 & $-2,02$ & 0,061 \\
& ENS-LHR & 0,06 & 0,17 & 0,37 & 0,720 \\
& ENS-LVR & 0,33 & 0,13 & 2,63 & $\mathbf{0 , 0 1 8}$ \\
\hline
\end{tabular}

-Associação estatisticamente significante em negrito $(p<0,05)$

Na Tabela 12, quando da movimentação anterior de ENA tem-se, em média, $231 \%$ de aumento de ANL. 
Tabela 12 - Associação entre todas as medidas em tecido duro (fatores) e o ponto ANL (variável resposta). Os coeficientes obtidos demonstram, em média, as proporções de aumento de ANL em relação à movimentação do tecido duro

\begin{tabular}{c|l|c|c|c|c}
\hline V. resposta & Fatores & Coeficiente & Erro-padrão & T & $p$ \\
\hline \multirow{6}{*}{ ANL } & Intercepto & 6,10 & 7,15 & 0,85 & 0,406 \\
& ENA-LHR & $-0,76$ & 1,04 & $-0,73$ & 0,474 \\
& ENA-LVR & 2,31 & 0,96 & 2,41 & $\mathbf{0 , 0 2 8}$ \\
& lis-LHR & 0,23 & 0,84 & 0,27 & 0,788 \\
& lis-LVR & $-1,13$ & 0,63 & $-1,79$ & 0,092 \\
& 7-LHR & 0,18 & 1,38 & 0,13 & 0,898 \\
& 7-LVR & $-0,74$ & 1,23 & $-0,61$ & 0,552 \\
& ENS-LHR & 2,28 & 1,44 & 1,59 & 0,132 \\
& ENS-LVR & 0,63 & 1,07 & 0,59 & 0,566 \\
\hline
\end{tabular}

-Associação estatisticamente significante em negrito $(p<0,05)$ 
Discussão 


\section{DISCUSSÃO}

Em diversos trabalhos realizados (Sarver e Johnston 1993, Ewing e Ross 1993, McCance et al 1997a, McCance et al 1997b, Al-Waheidi e Harradine 1998, Heliövaara et al 2000, Freitas 2001 e Heliövaara et al 2001), os pacientes com FTIU foram os mais estudados, seguidos dos pacientes com FTIB e fissuras palatinas (FP). Dentre estes estudos, a amostra mais ampla incluiu 10 pacientes para obtenção de dados relacionados ao tecido mole e a osteotomia LeFort I em indivíduos com FTIB. Nesse estudo, as cirurgias ortognáticas eram realizadas por diferentes cirurgiões (Heliövaara et al 2001), ocasionando assim, uma provável dificuldade no controle das variáveis da pesquisa. Desta forma, poucos dados relevantes podem ser aproveitados como parâmetros diretos de comparação entre o presente estudo e os demais. Por tanto, esta discussão será baseada na utilização de alguns trabalhos com amostra e metodologia similares.

Seguindo os valores das diferenças dos tempos T0 e T1 (medida pós-operatória menos a medida pré-operatória) submetidos ao teste "t" de Student pareado, esta avaliação demonstra que as medidas de movimentação vertical em tecido mole, em sua maioria e, a movimentação vertical de todos os pontos em tecido duro não foram significantes, enquanto todas as movimentações horizontais foram significantes. Esta análise comprova a escolha ideal dos casos que foram submetidos ao avanço de maxila com o mínimo de interferência de movimentos verticais, em concordância com objetivo proposto. Em comparação com os resultados aqui obtidos, Freitas (2001), analisando pacientes com FTIU e utilizando metodologia compatível, 
demonstrou uma movimentação significante em tecido mole no sentido horizontal, assim como na maioria das mudanças verticais do mesmo. A movimentação do tecido duro foi significante em todos os pontos no sentido horizontal e apenas em IC (Incisivo Central Superior) no sentido vertical. Na correlação entre a movimentação de tecido duro e mole após a cirurgia de avanço da maxila, as alterações horizontais foram todas significativas ao contrário de todas as verticais.

No presente estudo, as medidas verticais que apresentaram movimentação significativa (Tabela 4) foram Prn, Sn e A', bem demonstrada na Figura 12. Estas se encontram com suas medianas negativas, o que mostra a elevação do ápice nasal, SN e A'. O avanço da maxila foi comprovado pelas diferenças significativas de todas as medidas horizontais (Tabela 4), tanto no tecido duro quanto no mole (Figuras 12 e 13). Na Figura 15 observar-se o perfil cefalométrico da movimentação do tecido duro em relação ao mole, representado pela média das fases pré-operatória (vermelho) e pós-operatória (azul).

A comparação das medidas adicionais T0 e T1 mostra um aumento significativo do ângulo Naso-Labial (75\% dos casos) em conjunto com o aumento significativo do comprimento do lábio superior. Portanto, pode-se confirmar a melhora da estética facial nestes pacientes que, em sua grande maioria, se encontram com diminuição acentuada deste ângulo e deficiência do comprimento labial decorrente da insuficiência de tecido mole, em função das cirurgias reparadoras nesta área. Por outro lado, o aumento da espessura do lábio e a maior exposição do vermelhão labial, que se espera obter após a 
cirurgia, mostra-se igual ou mesmo diminuída. Isto sugere a falta de um dos passos cirúrgicos comprovadamente importante: a sutura do tipo $\mathrm{V}-\mathrm{Y}$ para o aumento volumétrico e comprimento labial, demonstrada por Nary Filho et al (2002).

Mesmo obtendo significância estatística apenas nas diferenças horizontais pré e pós-operatórias do avanço de maxila em indivíduos com FTIU, Heliövaara et al (2000) encontraram uma proporção média de $80 \%$ de acompanhamento do tecido mole em relação ao tecido duro no sentido horizontal e, $40 \%$ no sentido vertical, ressaltando que os pacientes tiveram suas medidas verticais aumentadas de $30 \%$ para $58 \%$ em relação à movimentação do tecido duro quando foram submetidos à execução da sutura do tipo $\mathrm{V}$-Y. O procedimento também manteve a espessura labial. Avaliando 10 pacientes com FTIB, Heliövaara et al (2001) notaram um aumento do comprimento do lábio superior (Sn-Sts) e diminuição da espessura labial (PrLs), de forma significante, sem o uso da sutura do tipo $\mathrm{V}-\mathrm{Y}$. Tal sutura não seria possível em um paciente com FTIB pela impossibilidade de se executar uma incisão contínua sobre o vestíbulo do arco superior, neste caso específico, prejudicando o aporte sangüíneo da pré-maxila (Posnick 1996).

Como meio final de tratamento estatístico, o Modelo de Regressão Linear Múltiplo (Neter e Kutner 1996) foi executado para a obtenção das proporções de acomodação do tecido mole com relação ao avanço da maxila, assim, seria possível mensurar a movimentação previsível do lábio superior e nariz destes pacientes. Considerando a necessidade, neste tipo de análise estatística, de um bom modelo a ser inserido na regressão, observa-se uma incompatibilidade biológica de algumas respostas significantes obtidas 
quando foram utilizadas as variáveis independentes 7 e ENS, observadas nas Tabelas 6, 8 11. Proporções elevadas entre a movimentação de ENS e 7 (posteriores) para pontos em tecido mole de lábio e nariz (anteriores) e movimentações contrárias do tecido mole à direção de movimento ósseo foram notadas. Desta forma, foram desconsiderados tais resultados pelo fato destes pontos não estarem diretamente relacionados à pré-maxila dos pacientes com FTIB, tendo em vista e, confirmando, assim, a independência de movimentos durante o ato cirúrgico, pois os ossos maxilares estão em três segmentos distintos.

Durante a interpretação dos dados obtidos, observa-se uma acomodação do tecido mole ao avanço de maxila compatível com outros estudos (Tabela 13), em sentido e direção, porém não em proporção. No trabalho de McCance et al (1997b) demonstrou-se uma proporção de $100 \%$ na região de maxila em linha média e caninos, em FTIB. Deve-se ressaltar que a amostra foi de apenas 6 pacientes e a tomografia computadorizada foi 0 método de imagem utilizado. Em pacientes com FTIU, no estudo de Freitas (2001), nenhuma movimentação inferior do tecido duro da maxila provocou mudanças significativas no tecido mole. As proporções obtidas para o tecido mole em relação ao avanço dos pontos lis e A foram maiores e significantes em relação à análise aqui realizada. Em comparação direta com as proporções significantes obtidas nos resultados do presente trabalho, o trabalho de Freitas (2001) mostra: 54\% de avanço de Ls e 66\% de Sts em relação ao avanço do ponto incisal do incisivo central. Para Al-Waheidi e Harradine (1998), além das significâncias das proporções horizontais, o ponto incisal do incisivo central também influencia no sentido vertical os pontos Ls $(44 \%)$ e Sts $(48 \%)$, em 
pacientes com fissuras transforame em geral. Ewing e Ross (1993), em pacientes com FTIU, encontraram uma proporção de $66 \%$ para Ls e $36 \%$ para Prn em relação ao avanço do lis, além de $63 \%$ para o ponto $S n$ em relação ao avanço do ponto $A$.

Em relação ao processo cirúrgico e seus resultados clínicos, é possível constatar que o perfil mole facial dos pacientes estudados foi melhorado, quando se considera, principalmente, as deficiências do ângulo Naso-labial e o comprimento do lábio superior, tornando, assim, a técnica eficiente em alguns quesitos. Quando se considera a diminuição da espessura e exposição do vermelhão labial, percebe-se que a impossibilidade da execução da sutura do tipo $\mathrm{V}-\mathrm{Y}$ pode ser um agravante ao resultado estético. Assim, a execução do enxerto ósseo alveolar (Trindade e Silva Filho 2007) previamente a cirurgia ortognática, seria um fator relevante ao resultado estético final do paciente com FTIB. A possibilidade de uma incisão contínua no vestíbulo maxilar proporciona a realização deste tipo de sutura, sem um déficit ao aporte sanguíneo da pré-maxila. Outra solução seria a execução de técnicas plásticas de cosmetologia não cirúrgica do lábio superior no intuito de preenchimento. 
Tabela 13 - Comparação entre estudos

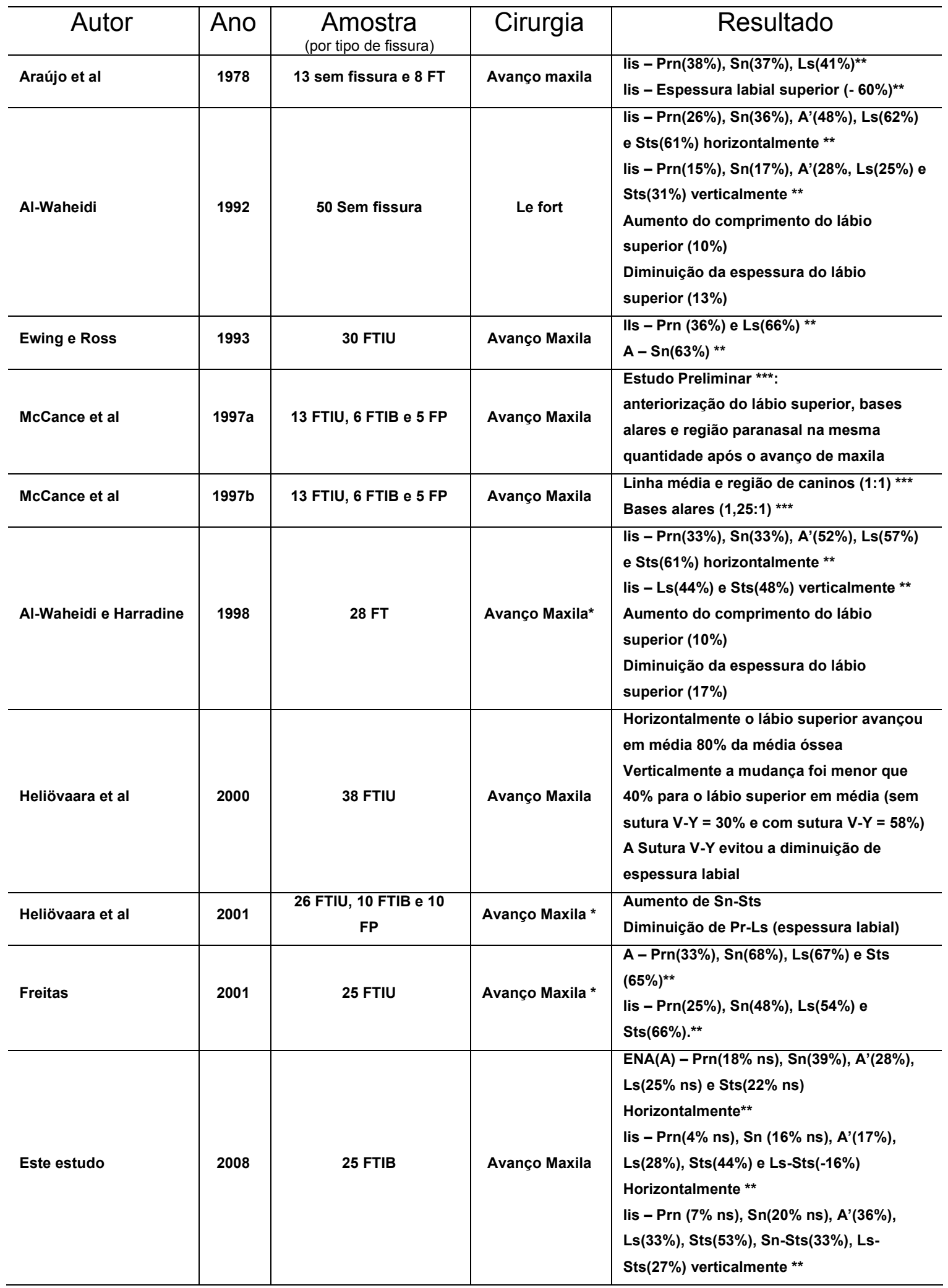

*Sem especificação de um único cirurgião como controle de variável

** Proporções de movimentação do ponto em tecido mole em relação ao ponto em tecido duro citado

*** Estudo em tomografia computadorizada, relação de regiões de tecido mole e tecido duro

ns: não significante estatisticamente

- : diminuição das medidas 
CONCLUSÃo 


\section{CONCLUSÃO}

Com os resultados e reflexões deste estudo, concluiu-se que:

- as medidas obtidas no avanço cirúrgico de maxila em pacientes com fissuras transforame bilaterais demonstraram a seguinte melhora estética: as alterações cefalométricas no sentido horizontal de todos os pontos estudados em tecido duro e mole apresentaram um avanço significante; no sentido vertical, apenas os pontos Prn, Sn e A' tiveram alterações significantes; e nas medidas adicionais estudadas, o aumento significante do ANL e Sn-Sts também foi observado.

- as proporções relativas à associação entre movimentação óssea e acomodação do tecido mole do perfil facial são menores em comparação às descritas na literatura para pacientes com outros tipos de fissura e pacientes sem fissuras. No entanto, a direção e sentido destas proporções coincidem com os achados no presente estudo.

Em observação final, nota-se que a insuficiência da espessura do lábio superior alcançada pelo avanço cirúrgico da maxila, poderia ser melhorada com a execução do enxerto ósseo alveolar previamente, possibilitando a realização de incisão contínua na maxila e, por conseqüência, a realização da sutura do tipo $\mathrm{V}-\mathrm{Y}$. 
REFEREANCIAS 


\section{REFERÊNCIAS}

Aiello CA. Efeitos ortopédicos e ortodônticos da tração reversa maxilar em pacientes com fissuras transforame Incisivo unilaterais. [dissertação]. Hospital de Reabilitação de Anomalias Craniofaciais - USP; 2005.

Almeida AM. Avaliação estética do perfil facial de indivíduos com fissura transforame incisivo unilateral reabilitados pelo Hospital de Reabilitação de Anomalias Craniofaciais. [dissertação]. Hospital de Reabilitação de Anomalias Craniofaciais - USP; 2005

Al-Waheidi EM. Soft tissue changes following maxillary osteotomies [dissertação]. Bristol: Bristol University; 1992.

Al-Waheidi EMH, Harradine NWT. Soft tissue changes in patients with cleft lip and palate following maxillary osteotomies. Cleft Palate Craniofac J 1998; 35:535-43.

Araújo A, Schendel SA, Wolford LM, Epker BN. Total maxillary advancement with and without bone grafting. J Oral Surg 1978; 36:849-58.

Ayoub AF. Soft tissue response to anterior maxillary osteotomy. Int $J$ Adult Orthodon Orthognath Surg 1991; 6:183-90. 
Baumann A, Sinko K. Importance of soft tissue for skeletal stability in maxillary advancement in patients with cleft lip and palate. Cleft Palate Craniofac J 2003; 40: 65-70.

Braun TW, Soltereanos GC. Orthognathic and secondary cleft reconstruction of adolescent patients with cleft palate. J Oral Surg 1980; 38:425-34

Ewing M, Ross RB. Soft tissue response to orthognathic surgery in persons with unilateral cleft lip and palate. Cleft Palate Craniofac J 1993; 30:320-7.

Freitas RZ. Avaliação do perfil mole em indivíduos com fissura labiopalatal submetidos à cirurgia ortognática. Estudo cefalométrico [dissertação]. Araçatuba: Faculdade de Odontologia de Araçatuba, Universidade Estadual Paulista; 2001.

Ferrari Júnior FM. Avaliação da estética facial de pacientes adultos com fissura transforame incisivo bilateral, reabilitados pelo protocolo de tratamento do Hospital de Reabilitação de Anomalias Craniofaciais. [dissertação]. Hospital de Reabilitação de Anomalias Craniofaciais - USP; 2005.

Heliövaara A, Hukki J, Ranta R, Rintala A. Changes in soft tissue thickness after Le Fort I osteotomy in different cleft types. Int $J$ Adult Orthodon Orthognath Surg 2001; 16:207-13. 
Heliövaara A, Hukki J, Ranta R, Rintala A. Soft tissue profile changes after Le Fort I osteotomy in UCLP patients. J Craniomaxilllofac Surg 2000; 28:25-30.

Heliövaara A, Ranta R, Hukki J, Rintala A. Skeletal stability of Le Fort I osteotomy in patients with isolated cleft palate and bilateral cleft lip and palate. Int J Oral Maxillofac Surg 2002; 31: 358-63.

lannetti G, Cascone P, Saltarel A, Ettaro G. Le Fort I in cleft patients: 20 years' experience. Craniofac Surg J 2004; 15:662-9.

Jensen AC, Sinclair PM, Wolford LM. Soft tissue changes associated with double jaw surgery. Am J Orthod Dentofac Orthop 1992; 101:266-75.

Lauris RCMC. Avaliação da estética facial de pacientes com fissura transforame incisivo bilateral, submetidos ao protocolo de cirurgias do HRACUSP. [dissertação]. Hospital de Reabilitação de Anomalias Craniofaciais USP; 2005

McCance AM, Moss JP, Fright WR, Linney AD, James DR. Three-dimensional analysis techniques--part 1: three-dimensional soft-tissue analysis of 24 adult cleft palate patients following Le Fort I maxillary advancement: a preliminary report. Cleft Palate Cranifac J 1997a; 34: 36-45.

McCance AM, Moss JP, Fright WR, Linney AD, James DR, Coghlan $\mathrm{K}$ et al. Three-dimensional analysis techniques - part 4: Three-dimensional analysis of 
bone and soft tissue to bone ratio of movements in 24 cleft palate patients following Le Fort I osteotomy: a preliminary report. Cleft Palate Craniofac $J$ 1997b; 34: 58-62.

Mehra P, Wolford LM, Hopkin JK, Castro V, Freitas R. Stability of maxillary advancement using rigid fixation and porous-block hydroxypatite grafting: cleft palate versus non-cleft patients. Int J Adult Orthod Orthognath Surg 2001; $16: 193-9$.

Morettin PA, Bussab WO. Estatística básica. Saraiva: São Paulo; 2006.

Nary Filho H, Gonçales ES, Berretin-Felix G, Souza PCU, Achôa GL. Evaluation of the facial soft tissues following surgically assisted maxillary expansion associated with the simple $\mathrm{V}-\mathrm{Y}$ suture. Int $\mathrm{J}$ Adult Orthodon Orthognath Surg 2002; 17:89-97.

Neter J, Kutner MH, Wasserman W, Nachtsheim CJ. Applied linear statistical models. $4^{\text {th. }}$ ed. New York: McGraw-Hill/Irwin; 1996.

Posnick JC. Orthognathic surgery for the cleft lip and palate patient. Semin. Orthod 1996; 2:205-14.

Radney LJ, Jacobs JD. Soft-tissue changes associated with surgical total maxillary intrusion. Am J Orthod 1981; 80:191-212. 
Sarver DM, Johnston MW. Orthognathic surgery and aesthetics: planning treatment to achieve functional and aesthetics goals. $\mathrm{Br} J$ Orthod 1993; 20:93100.

Silva Filho OG, Freitas JAS, Okada T. Fissuras labiopalatais: diagnóstico e uma filosofia interdisciplinar de tratamento. In: Pinto VG. Saúde bucal coletiva. $4^{\mathrm{a}}$ ed. São Paulo: Santos; 2000. p.481-527.

Suguimoto RM. Avaliação da estabilidade pós-cirúrgica em indivíduos portadores de fissura labiopalatina, submetidos à cirurgia ortognática: estudo cefalométrico através do programa computadorizado Cef- $X$ [tese]. Araçatuba: Faculdade de Odontologia de Araçatuba, Universidade Estadual Paulista; 2002

Tindlund RS, Rygh P. Soft-tissue profile changes during widening and protraction of the maxilla in patients with cleft lip and palate compared with normal growth and development. Cleft Palate Cranifac J 1993; 30:454-68.

Trindade IEK, Silva Filho OG, coordenadores. Fissuras labiopalatinas: uma abordagem multidisciplinar. São Paulo: Ed. Santos; 2007. 
ANEXOS 


\section{Anexo 1 - Ofícios da Unidade de Ensino e Pesquisa - Hospital de Reabilitação de Anomalias Crânio Faciais da Universidade de São Paulo.}

Ofício $n^{\circ} 332 / 2005-\mathrm{UEP}-\mathrm{CEP}$

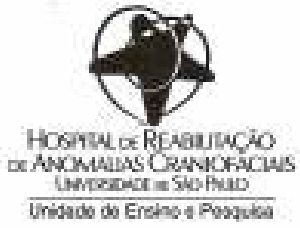

Bauru, 15 de dezembro de 2005.

Prezado(a) Seahor(a)

O projeto de pesquisa encaminhado a este Comitê de Ética em Pesquisa em Seres Humanos, denominado "Análise do perfil mole facial frente ao avanso cirúrgico da maxila em pacientes com flssuras labiopalatinas", de autotia de GUSTAVO LARA ACHÔA desenvolvido sob sua orientaçăo, foi enviado ao relator para avaliaçăo.

O parecer do relator, aprovando o projeto, foi aceito pelo Comitê,, cronsiderando que não existem infraçōes éticas pendentes para inicio da pesquisa. Solicitamos a V.S* a gentileza de comunicar o parecer a pesquisador.

O pesquisador fica responsável pela entrega na Unidade de Ensino e Pesquisa dos relatórios semestrais, bem como comunicar ao CEP todas as alteraçốes que possam ocorrer no projeto.

Informamos que após o recebimento do trabalho concluido, este Comitế enviará o parecer final para publicaçẵo.

Atenciosameate

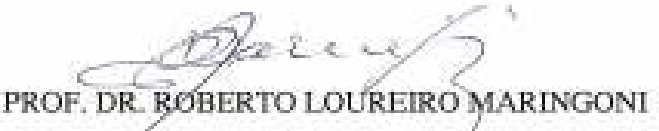

Coordenador do Comitê de Ética em Pesquisa do HRAC-USP

llma. Sra.

Dra. Terumi Okada Ozawa

Ortodontia-HRACIUSP

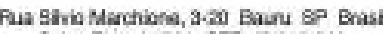
Cana Pental 1:501 CEP 17,012000

Te. 551430353421 Fax $5514 \$ 034764$ Emal ansoovepilor 
Oficio $n^{a} 366 / 2006-S V A P E P E-C E P$

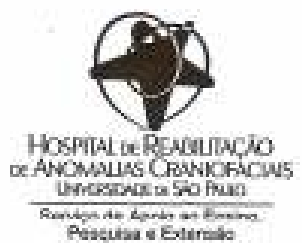

Bauru, 04 de dezembro de 2006.

Prezado(a) Serhor(n)

O projeto de pesquisa encaminhado a este Comitê de Ética em Pesquisa em Seres Humanos, denominado "Análise do perfil mole facial frente ao avanço ciruirgico da maxila em pacientes com fiscuras Iahiapalorinas", de autoria de GUSTAVO LARA ACHÔA desenvolvido sob sua orientaçăo, foi enviado to relator para avaliaçào.

Na reunião de 29/11/2006 o parecer do relator, aprovando o projeto, foi aceito pelo Comitê, considerando que nāo existem infraçốes éticas pendentes para inicio da pesquisa. Solicitumos a V.S a gentileza de comunicar o parecer ao pesquisudor e anexar o presente oficio as jumjetn, pois o mesmo será necessário pura futura publicação do trabalho.

O pesquisador fica responsivel pela entrega no Serviço de Apoio ao Ensino, Pesquisa e Extensảo dos relatónios semestrais, bem como comunicar à CEP todas as alteraçōes que possam correr no projeto.

Informamos que apốs o recebimento do trabalho concluido, este Comitê cnviará o parceet final para publicaçån

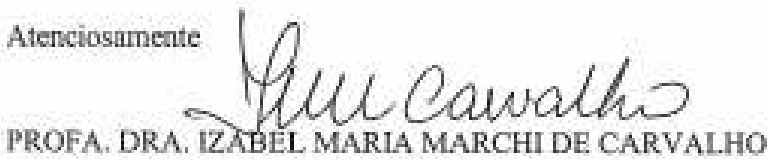

Vice-Coordenudora, em exercicio, do Comité de Etiea enn Pesquisa em Seros Humanos: do HRAC-USP

$1 \mathrm{mo}(\mathrm{a}) \mathrm{Sr}(\mathrm{a})$

Dra. Terumi Okada Ozawa

Ortodontia HRACUSP

Pas Sevio Martione. 3 -20 Baun SP Brab Caba Fosial 1501 CEP 17.012 .000 Fas 8421 fax 56142734781 


\section{Anexo 2 - Carta de informação ao sujeito da pesquisa e Termo de consentimento livre e esclarecido}

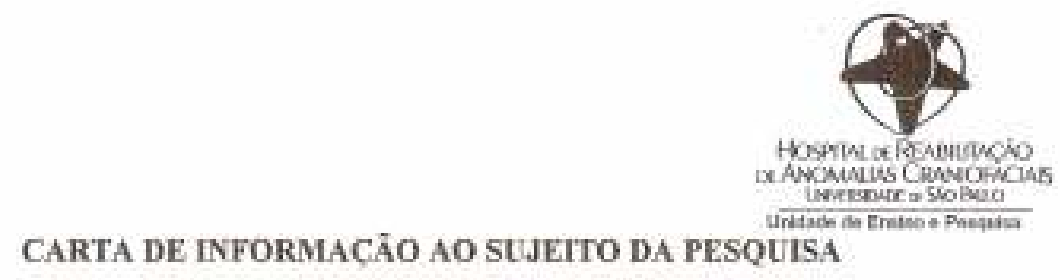

$\operatorname{Sr}(a)$

O Hospital de Reabilitaçăo de Anomalias Craniofacial - HRAC (O Centrinho) esta realizando a pesquisa "Análise do perfil mole facial frente ao avanço cinìngico da maxila em pacientes com fissuras labiopolatimus" para acompantar as mudanças que acontecem no rosto dos pacientes que foram submetidos à Cirurgia Ortognatica. Estas mudanças ainda são pouco conhecidas e desta forma ajudaremos a melhorar o trataroento cinirgico dos pacientes com fissuras labiopalatinas. Nesta pesquisa utilizaremos as radiografias tiradas antes e depois da cirurgia, para que possamos fazer medidas nestas radiografias.

Deixamos claro que apenas utilizaremos radiografias, sem nenhum procedimento direto no paciente, e que nĩo hé qualquer desconforto ou risco causado por esta pesquisa, pois estas radiografias, se já nēo foram tiradas, serḋo tisadas dentro do prazo padronizado pelo hospital, para total seguranca do paciente.

E garantido aos pacientes participantes, toda e qualquer informação sobre esto pesquisa, suas condutas e resultados obtidos atualizados. As informaçōes podem ser solicitadas diretamente a quem apresenta esta carta ou outro responshvel, em qualquer momento durante o tempo de estudo.

A participaçåo não é obrigatória e para deixar de participar da pesquisa é necessário apenas solicitar a desisténcia ao responsável, em qualquer momento do tempo de estudo, sabendo que nio haverá alteraçào ou prejuizo no tratamento do paciente decorrente desta desisténcia.

Fica assegurado o sigilo da ideatidade ou qualquer informaçāo relacionada à privacidade dos participantes desta pesquisa em qualquer momento durante e apos o término do estudo.

\section{Obrigado}

"Caso o sujeito da pesquisa queira apresentar reclamaçbes en relação a sua participaçia nu pesquisa, poderá entrar em contato còn o Comitê de Ética em Pesquisa em Seres Humanos, do HRAC-USP, pelo endereso Ras Silvio Marchione, 3-20 na Unidade de Ensino e Pesquisa ou pelo telefone (14) 3235 . $8421^{\prime \prime}$

Eump

Nano do sujciso ou responsivel:

Assinatura do sejesto cu respansivel:

Nome do pesquissdor responstivel: GUSTAVO LARA ACHOA

Assinatura do pesqueabcr reppensiod:

Roue ahdo Marctions, 9-20 Basu Sp thas: curne pesta 1501 cop $17012-900$

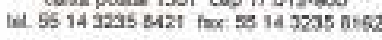




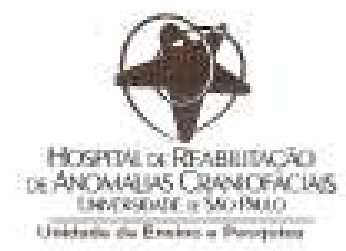

TERMO DE CONSENTIMENTO LIVRE E ESCLARECIDO

Pelo presente instrumento que atende as exigencias legais, o Sr. (a)

portador da cédula de identidade * responsárvel pelo paciente apos ieitura minuciosa da CARTA DE INFORMACÁO AO SUJETTO DA PESQUISA, devidamente explicada pelos profissionais en seus minimos detalhes, ciente dos serviços e procedimentos aos quais será submetido, rão restando quaisquer dividas a respeito do lido e explicado, firma seu CONSENTIMENTO LIVRE E ESCLARECIDO concordando em participar dn pesquisa: "ANALISE DO PERFIL MOLE FACIAL FRENTE AO AVANCO CIRURGICO DA MAXILA EM PACIENTES COM FISSURAS LABIOPALATINAS", realizada por: GUSTAVO LARA ACHỎA n ${ }^{\circ}$ do Conselho: CROSP 72561, sob orientaçio dn Dra. TERUMI OKADA OZAWA, $\mathrm{n}^{\circ}$ do Conselho: CROSP 23742

Fica claro que o sujeito da pesquisa ou seu representante legal, pode a qualquer momento tetirar seu CONSENTIMENTO LIVRE E ESCLARECIDO e deixar de participar desta pesquisa e ciente de que todas as informaçóes prestadas tomaram-se confidenciais e guardadas por força de sigilo profissional (Art. 10 do Código de Etica Odontológica).

Por estarem de acordo assinam o presente termo.

Baun-SP, de de:

Assinatura do Sujeito da Pesquisa Assinatura do Pesquisador Responsável ou responsavel

\section{* A SER PREENChIDO, SE O SUJEITO DA PESQUISA NÃo FOR O PACIENTE.}

Nome do Pesquisador Responsaivel: GUSTAVO LARA ACHŌA

Endereço do Pesyutisador Responsável (Rua, No): Rua Caetano Sampieri 7-60 Apto. 72

Cidade: Baunu Estado:SP CEP: 17011-133

Telefone: (14)8115-2644 E-mail: glachoaglyahoo som bf

Endereco Institucional (Rua, No): Rua Silvio Marchione 3-20

Cidade: Baura Estado: SP CEP: 17012-900

Telefone: (14)3235-8000 Ramal: 8095 


\section{Anexo 3 - Interpretação dos Boxplots}

Fronteira que

determina se o indivíduo é extremo

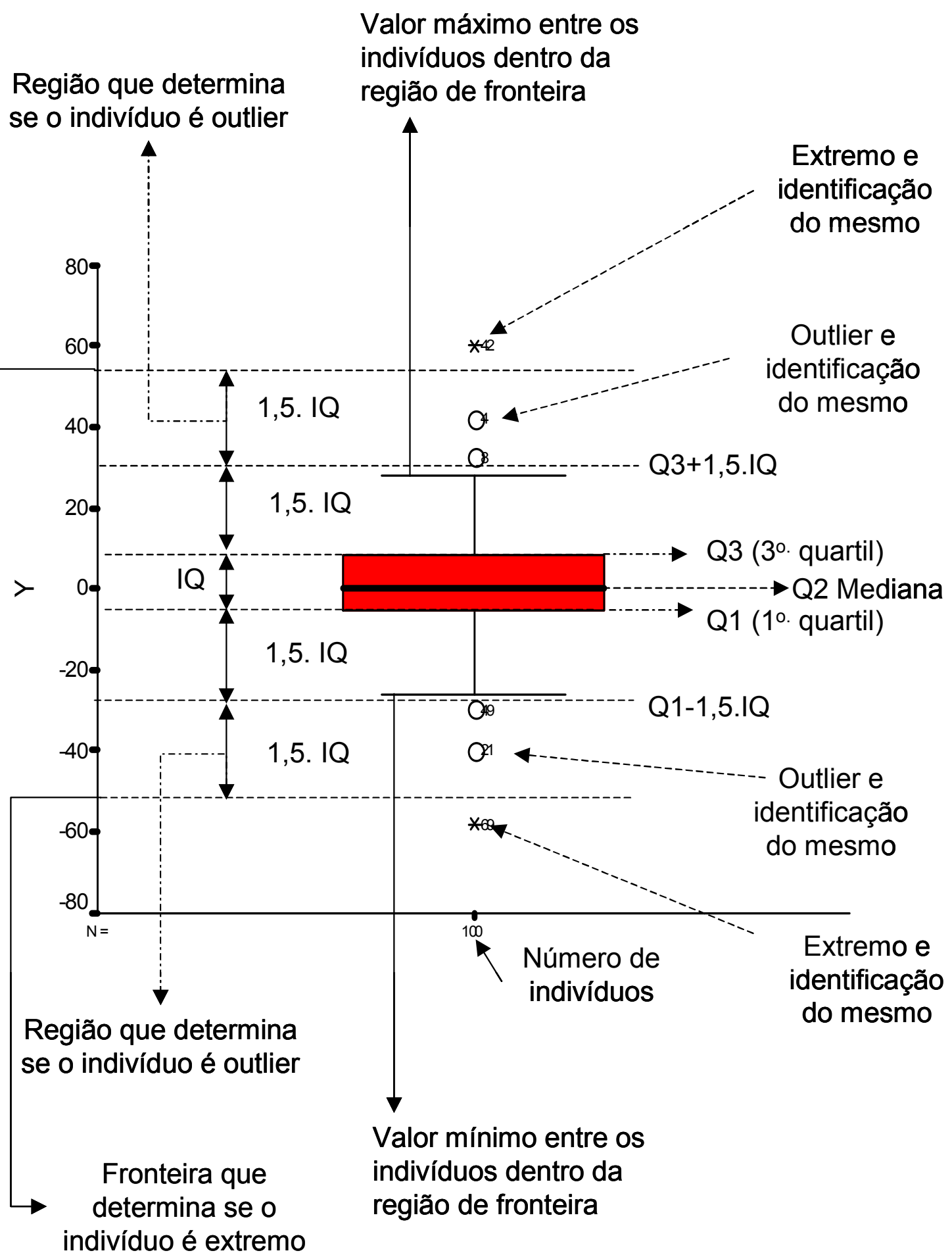


Anexo 4 - Fotos e Radiografias utilizadas na pesquisa nos períodos pré (esquerda) e pós-operatório (direita)

Caso 01

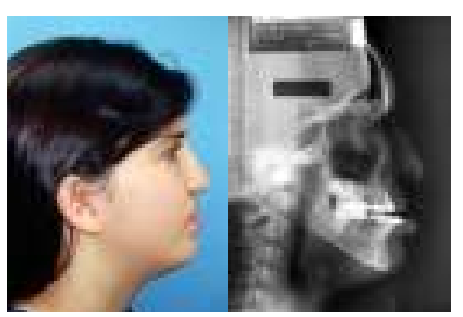

Caso 02

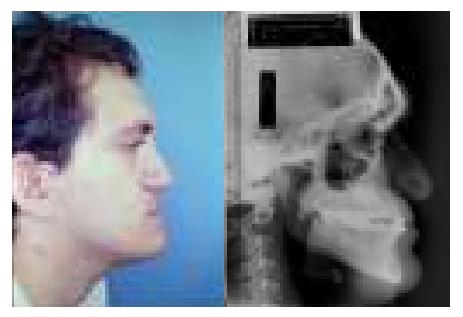

Caso 03

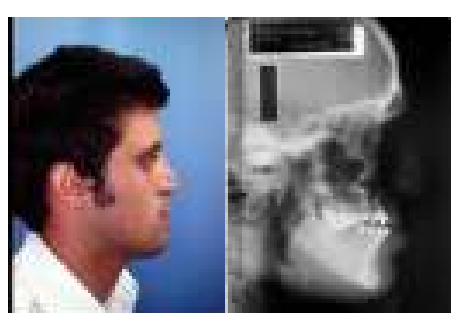

Caso 04

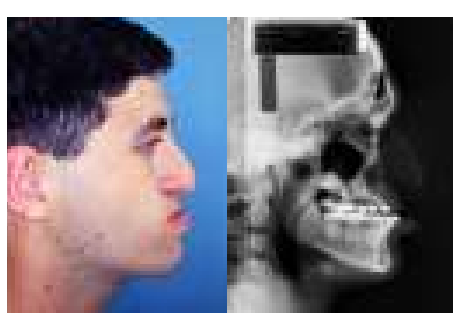

Caso 05

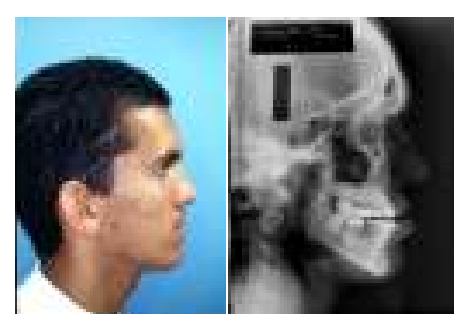

Caso 06

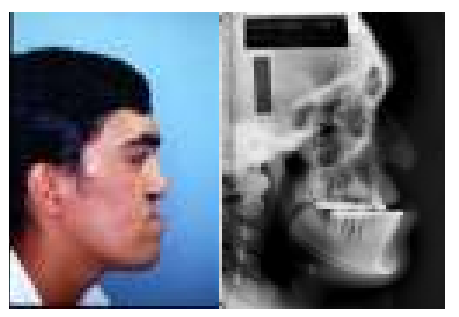

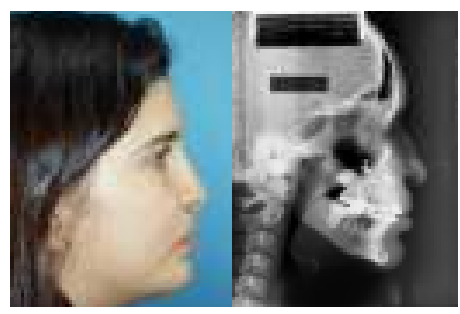
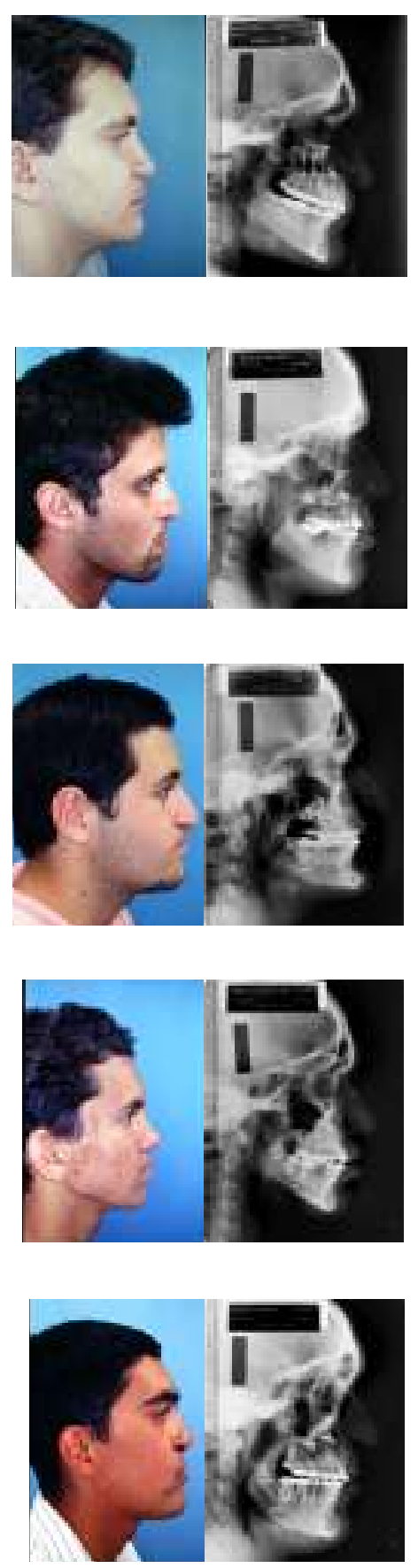

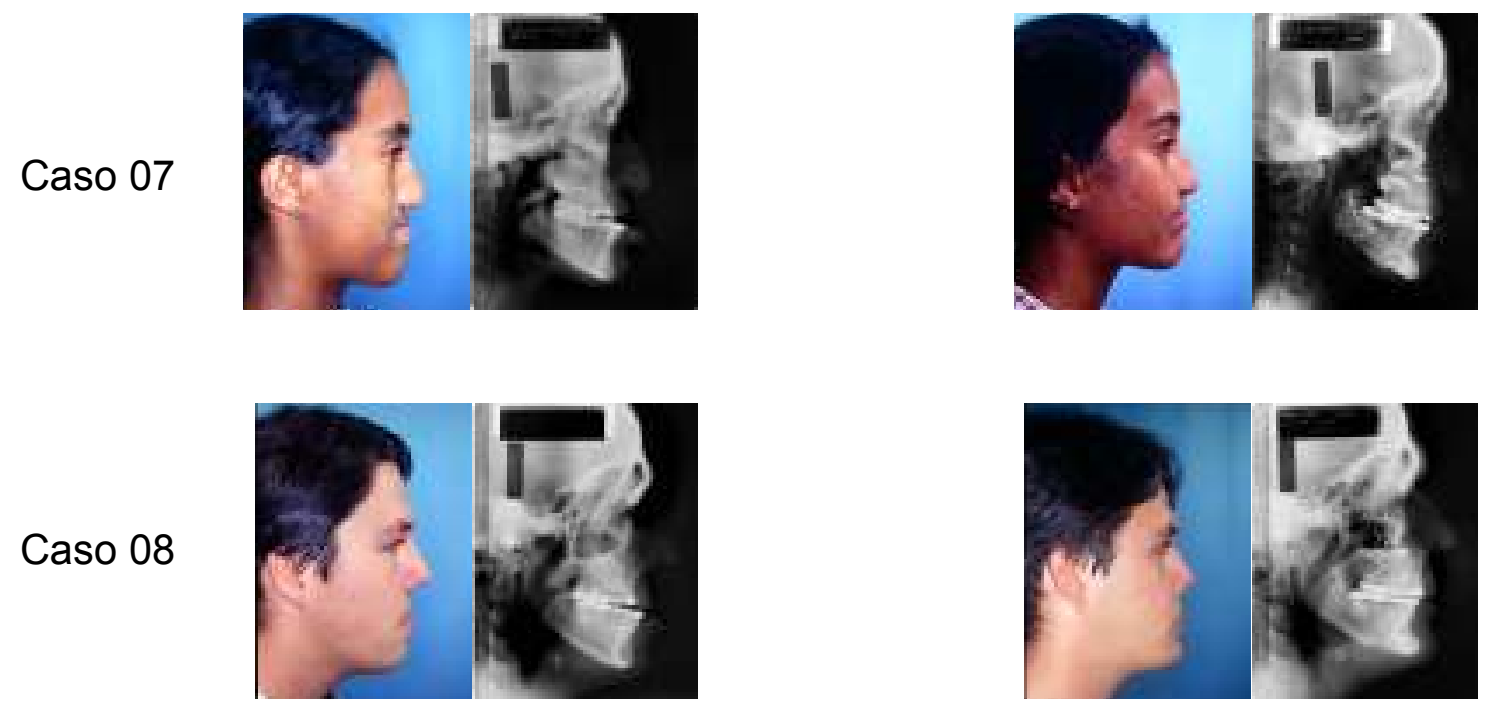

Caso 09
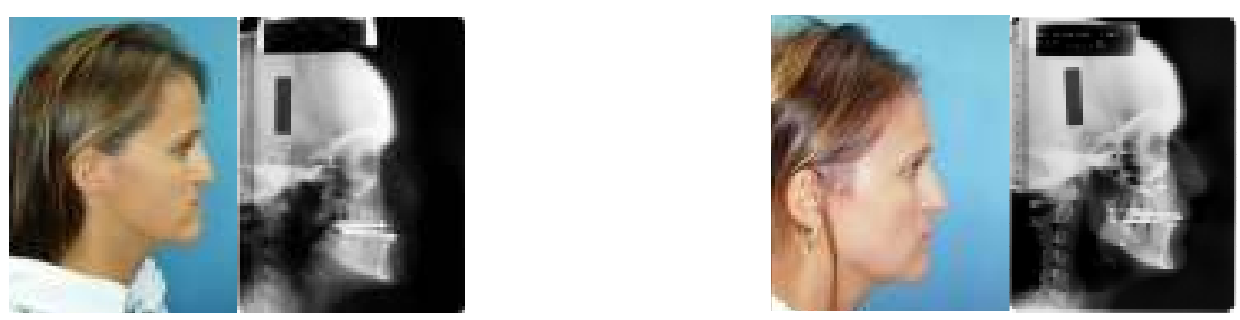

Caso 10
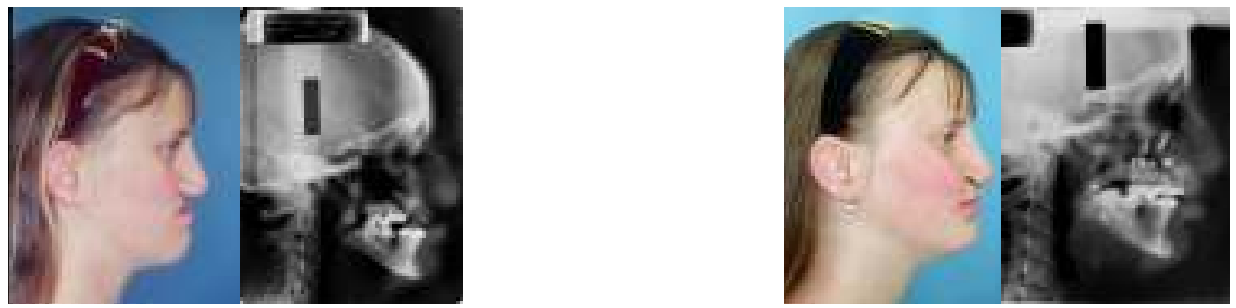

Caso 11
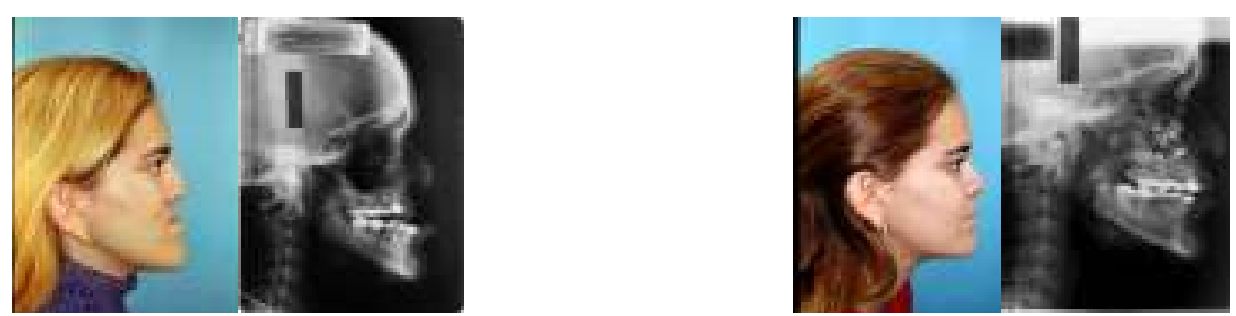

Caso 12
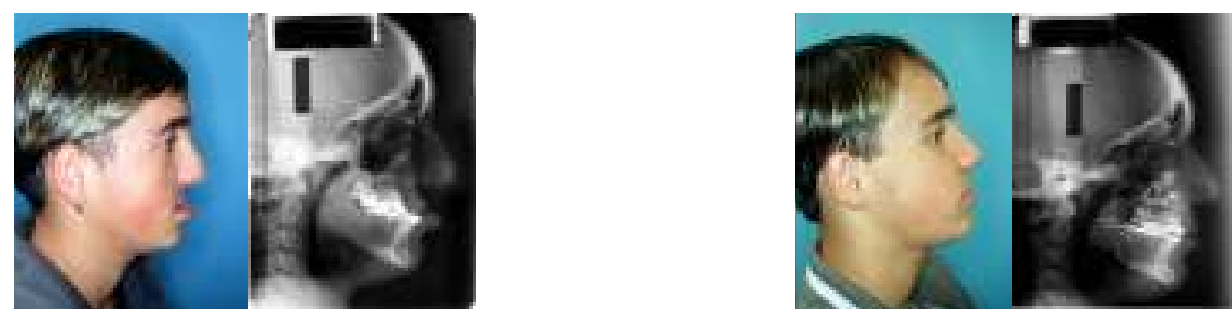

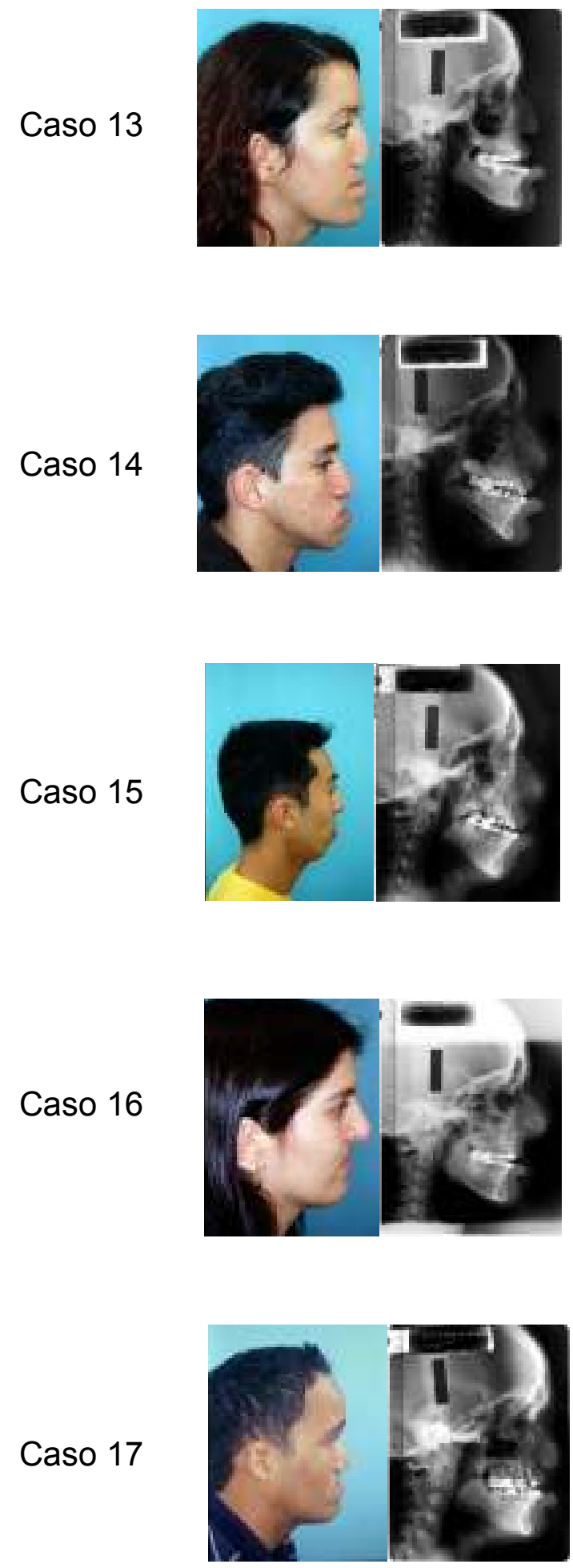

Caso 17

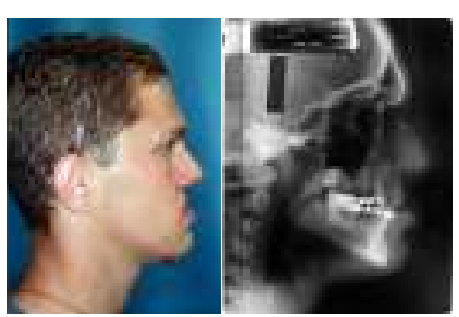

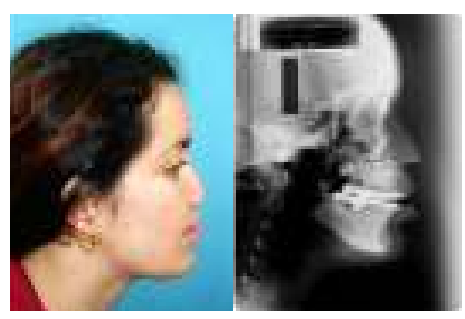
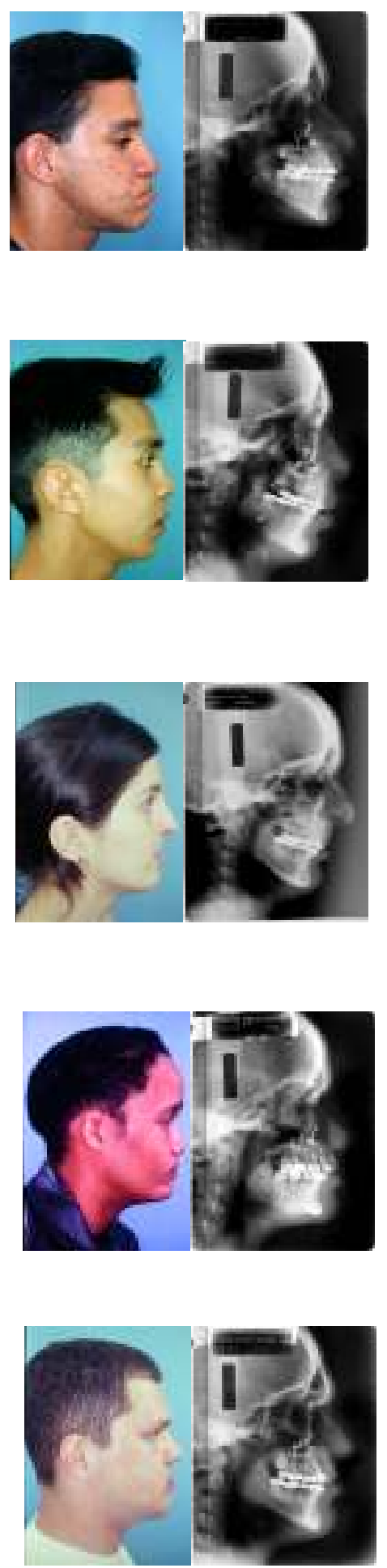
Caso 19
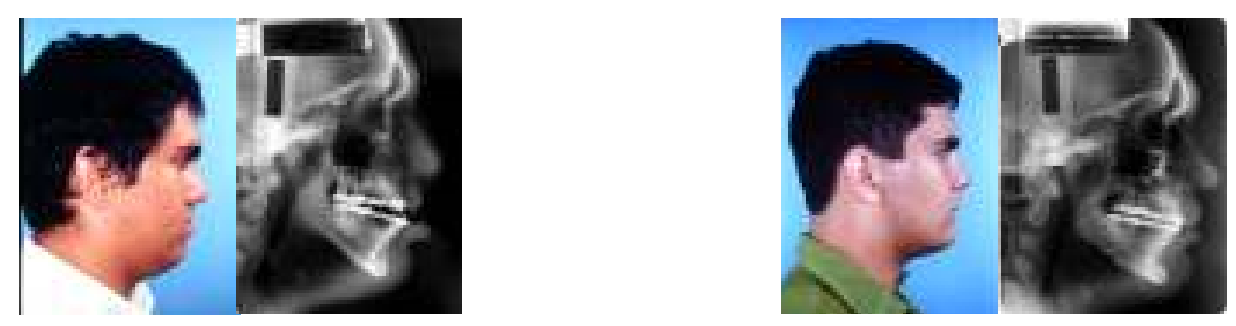

Caso 20
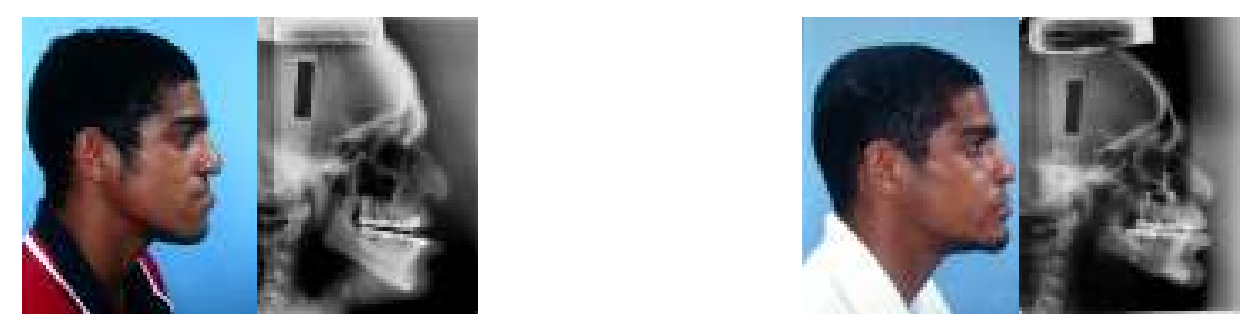

Caso 21
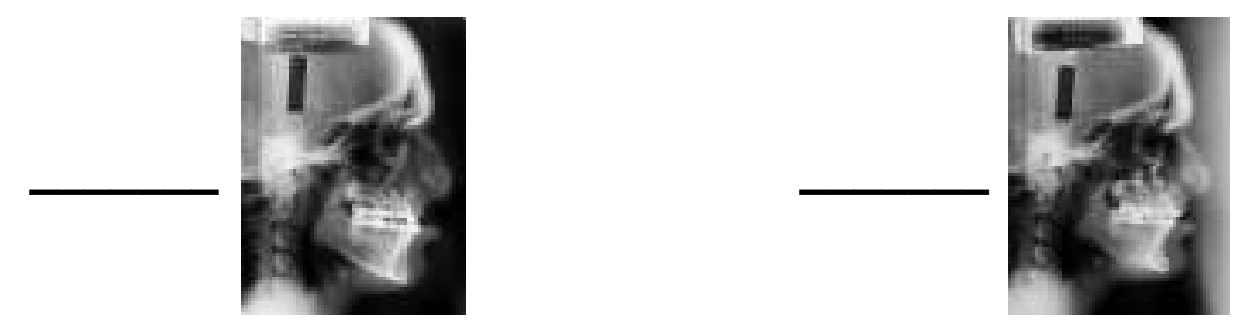

Caso 22
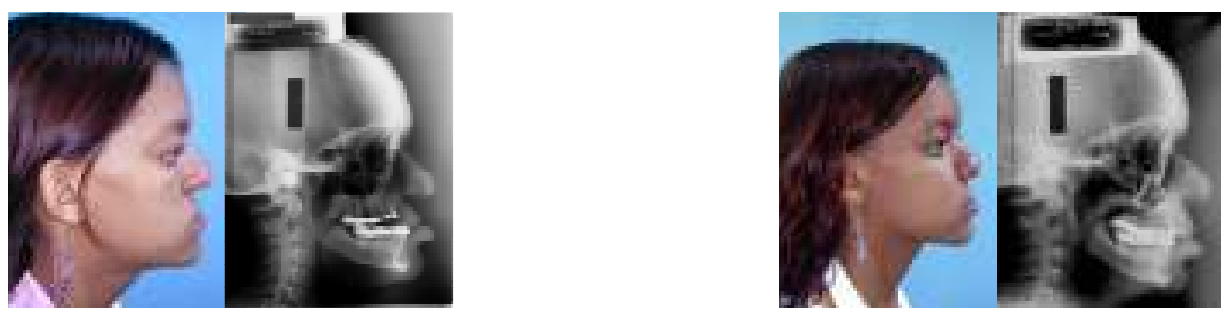

Caso 23
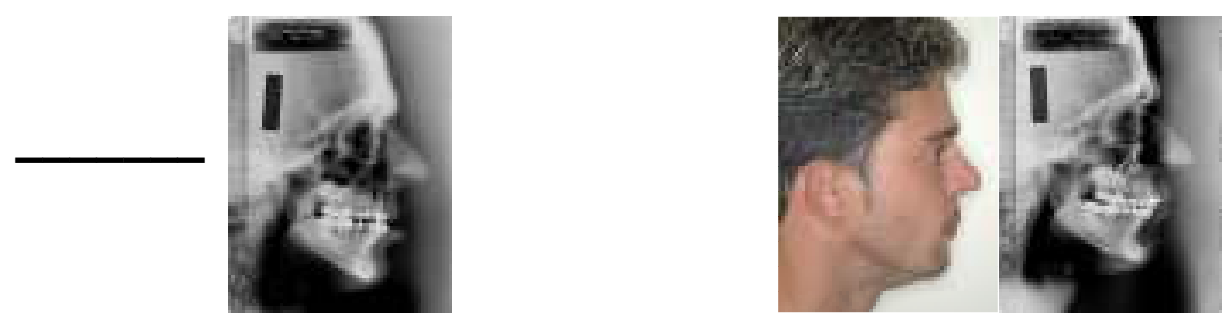

Caso 24
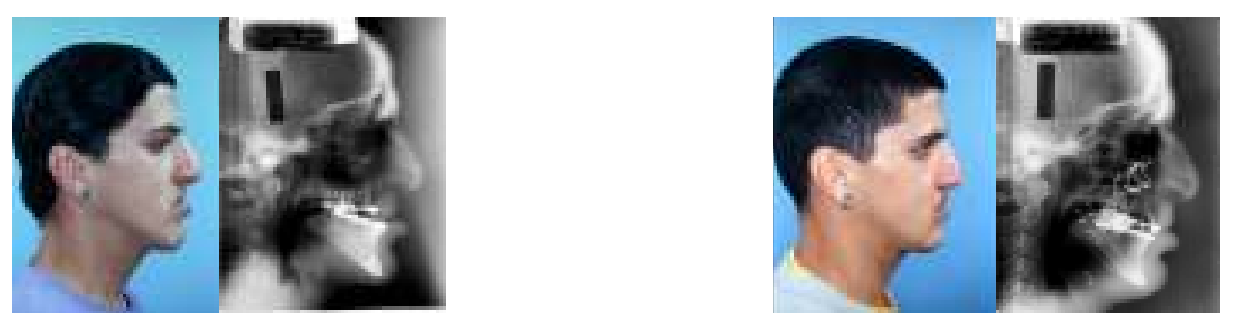


\section{Caso 25}
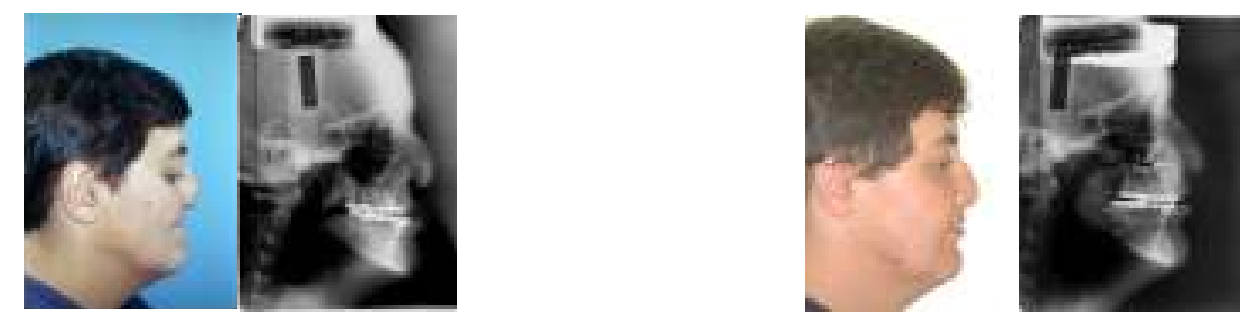

: não encontrada 